\title{
拡大および縮小テーパ環を有する円形噴流の流れ特性
}

\author{
臼沢 太-*11，木綿 隆弘 ${ }^{* 2}$, 平野 大慈*3
}

\section{Flow characteristics of a round jet with divergent and convergent tapered annulus}

\author{
Taichi USUZAWA*1, Takahiro KIWATA*2 and Daiji HIRANO*3 \\ ${ }^{* 1, * 3}$ Graduate School of Natural Science and Technology, Kanazawa University \\ Kakuma-machi, Kanazawa-shi, Ishikawa 920-1192, Japan \\ ${ }^{* 2}$ School of Mechanical Engineering, Kanazawa University \\ Kakuma-machi, Kanazawa-shi, Ishikawa 920-1192, Japan
}

\section{Received 17 March 2014}

\begin{abstract}
The flow characteristics of round air jets with tapered annulus was investigated experimentally. The divergent and convergent tapered annulus was installed concentrically inside of the round nozzle. The effects of the length of annulus, the diameter of annulus on the mean and fluctuating velocities, and the velocity ratio of the inner jet to outer jet at the nozzle exit were examined by the hot-wire measurement and flow visualization. In the case of the jets with the divergent tapered annulus, the outer jet was accelerated and the inner jet was decelerated. The spread of jet with the divergent tapered annulus increased in the near field of the jet. On the other hands, with convergent tapered annulus, the outer jet was decelerated and the inner jet was accelerated. The spreads of round jet with the convergent tapered annulus was smaller than the other jet. It is found that the flow characteristics of a round jet with tapered annulus was the similar to that of a plane jet with deflecting plates.
\end{abstract}

Key words : Jet, Nozzle, Flow control, Flow measurement, Flow visualization, Mean velocity, Turbulent intensity, Divergent tapered annulus, Convergent tapered annulus

\section{1. 緒言}

円形噴流や同軸噴流はジェットエンジンやエアジェットルームなど様々な産業機器に応用されており，その流 れを制御することは機器の性能向上において重要である。噴流は自由せん断層内に発生する渦構造により支配さ れており，この渦構造を解明することは噴流の流れ特性制御につながる. 特に，近年では外部からのエネルギー 供給に依存しない噴流の受動的制御が省エネルギーの観点から注目されている.

円形噴流の受動的制御として，噴流の自由せん断層内にタブやブラフボディを設置して乱れを与える方法があ る.例えば, Parker ら(Parker, et al., 2003)はレイノルズ数 Re $=2.35 \times 10^{4}$ の円形噴流においてノズル出口近傍に $\phi 0.5 \mathrm{~mm}$ の円形断面のリングを設置した場合に，混合層の成長がリングによって抑制されることを明らかにした．Sadeghi ら(Sadeghi and Pollard, 2012)はレイノルズ数 $R e=1.0 \times 10^{4}, 3.0 \times 10^{4}, 5.0 \times 10^{4}$ の円形噴流の自由せん断層内に一辺 $1.5 \mathrm{~mm}$ の正方形断面のリングを設置した場合に噴流の広がりが抑制され，卓越周波数が生じなくなることを明ら かにした. また, Callender ら(Callender, et al., 2010)によって Chevronノズルからの流れ場が粒子画像流速測定法 (PIV)によって計測され, タブによって噴流中心の速度減衰を早め, ポテンシャルコア長さが短くなることを示し た. そして，円形噴流のポテンシャルコア内にブラフボディなどを設置して後流による乱れを付加することで噴 流を受動的に制御する方法も行われている．例えば，Burattini ら(Burattini, et al., 2004), (Burattini and Djenidi, 2004) はレイノルズ数 $R e=4.9 \times 10^{4}$ の円形噴流のノズル出口に設置した格子により発生した乱れが円形噴流の流れ場に与

\footnotetext{
No. 14-00152 [DOI: 10.1299/transjsme.2014fe0256]

*1 正員, 金沢大学大学院自然科学研究科（干920-1192 石川県金沢市角間町）

*2 正員, 金沢大学理工研究域機械工学系

*3 金沢大学大学院自然科学研究科

E-mail of corresponding author: usuzawa@ryuko.ms.t.kanazawa-u.ac.jp
} 
える影響を実験と線形不安定性解析で調べた. Sadeghi ら(Sadeghi and Pollard, 2012)は円形噴流のポテンシャルコ ア内に正方形断面のリングを設置した場合においても噴流の広がりが抑制され，リングによって卓越周波数が生 じなくなることを明らかにした．以上のような受動的制御手法によって噴流のエントレイメントの抑制やポテン シャルコア長さの減少が可能となる.

また，同軸噴流の受動的制御としては，内側噴流と外側噴流の速度比によってせん断層の速度勾配を变化させ る方法がある．同軸噴流の速度比 $U_{\mathrm{i}} / U_{\mathrm{o}}\left(U_{\mathrm{i}}\right.$ : 内側円形噴流速度， $U_{\mathrm{o}}$ : 外側環状噴流速度)を变化させることによる制 御については多くの研究が行われており, 内側噴流の速度が外側噴流の速度よりも速い速度比 1 以上のものと, 内側噴流の速度が外側噴流の速度よりも遅い速度比 1 以下のものに大別できる. まず，速度比が 1 以上の条件で 同軸噴流の流れ特性を調べたものとして, Champagne ら(Champagne and Wygnanski, 1971)がレイノルズ数 $R e=1.0 \times 10^{4}$ から $1.0 \times 10^{5}$ の速度比が 4 までの定常特性を示し, 同軸噴流の内側噴流のポテンシャルコア長さは速度 比 1.0 以上では, 外側噴流によって内側噴流との間のせん断層が弱められるため, 円形噴流よりも長くなること を明らかにした. Ko ら(Ko and Kwan, 1976)が速度比 $U_{\mathrm{i}} / U_{\mathrm{o}}=1.4,2.0,3.3$ の乱れ強さの相似性や渦構造を調べてい る. Mergheni ら (Mergheni, et al., 2008)は，速度比を $U_{\mathrm{i}} / U_{\mathrm{o}}=0.54 \sim 5.17$ に変化させ，レーザ流速計(LDA)による計測 で, 速度比 $U_{\mathrm{i}} / U_{0} \geq 1.0$ において内側噴流のポテンシャルコア長さが速度比に強く依存することを明らかにした. このように, 速度比 1 以上の同軸噴流では, 速度比とポテンシャルコア長さ増加の関係性が議論されている.

一方, 速度比が 1 以下の条件で同軸噴流の流れ特性を調べたものとして, Ko ら(Ko and Au, 1981)は速度比 $U_{\mathrm{i}} / U_{\mathrm{o}}=0.4,0.6,0.8$ の同軸噴流で外側, 内側混合領域の平均速度や乱れ強さに相似性が存在することも示した. 木 綿ら(木綿他, 1994)は同軸二重円管噴流について速度比を $U_{\mathrm{i}} / U_{\mathrm{o}}=0.1 \sim 0.5$ に変化させて流れ場を計測し, 内側ノズル 出口下流に再循環領域が形成され, 速度比が小さいほど再循環領域が拡大寸ることを示した. Buresti ら(Buresti, et al., 1998)は, 速度比 $U_{\mathrm{i}} / U_{\mathrm{o}}=0.3$ で実験を行い, 内側噴流のポテンシャルコア長さは速度比の減少と共に短くなり, 内側ノズルの厚さを薄くすることで, 内側せん断層の乱れ強さが減少することを明らかにした. Warda ら(Warda, et al., 1999)は, 速度比 0.64 の同軸噴流において内側噴流のポテンシャルコア長さの速度比依存性を示し, 速度比 $U_{\mathrm{i}} / U_{0} \geq 1$ の同軸噴流よりも発達が早いことを明らかにした. よって, 速度比 1 以下の同軸噴流では, 内側噴流出 口下流に再循環領域が形成され, 内側噴流のポテンシャルコア長さも速度比に依存し, 内側せん断層内の乱れ特 性が内側ノズルの形状に影響されることを明らかにしている.

以上のように，同軸噴流は，単なる円形噴流と異なり，速度比によって流れ特性が変化する. すなわち，円形 ノズルの内部に円形噴流を内側噴流と外側噴流に分離するテーパ環を設置し，そのテーパ環の形状によって速度 比を変化させることで, 円形噴流の受動的制御の可能性があると考えられる. また, Sadeghi らが行ったように円 形噴流に矩形断面のリングを設置することでノズル出口近傍領域から遷移領域の流れ特性が変化することからも, 本手法で円形噴流の流れ特性に変化を与えることができると推測する. この考え方に基づき, 著者ら(臼沢他, 2013)は, 二次元噴流への適用を行い, 平面噴流に偏向板を設置することで簡易的に二次元の同軸噴流を形成させ, 偏向板の長さや角度を変化させることでその流れ特性を調べた。その結果，偏向板によって流れ特性の制御が可 能であることを示し，縮小偏向板を設置した場合に平面噴流の広がりが抑制されることを明らかにした．速度比 の変更は偏向板の長さと角度で行い, 偏向板長さを変化させる方が角度を変化させるよりも流れ特性の制御に対 して効果的であることを示した.

本報では，偏向板を有する二次元噴流と同様な制御を軸対称噴流でも行うために，円形噴流のノズル内部に拡 大テーパ環または縮小テーパ環を設置することで簡易的に速度差が生じる同軸噴流を形成させ，特に，テーパ環 の長さ, 直径が円形噴流の流れ特性に与える影響を明らかにして, 円形噴流の発達の制御の可能性を調べる. そ して，偏向板を有する平面噴流の結果と比較することで軸対称噴流の拡大・縮小テーパ環による制御方法につい て報告する。

\section{2. 実験装置および実験方法}

\section{$2 \cdot 1$ 実験装置}

本研究で使用した実験装置の概略図を図 1 に, 供試ノズルとテーパ環の概観図と断面図を図2にそれぞれ示す. スクリュー圧縮機(日立製作所製，OSP-15UA)から供給された空気が，チャンバー内の整流格子，絞り比 20.25 の 


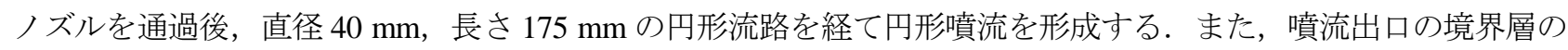
排除厚さは, $\delta^{*}=0.786 \sim 1.09\left(U_{0}=8 \mathrm{~m} / \mathrm{s} \sim 20 \mathrm{~m} / \mathrm{s}\right)$ であり, 形状係数が $H\left(=\delta^{*} / \theta, \theta\right.$ : 運動量厚さ $)=2.5 \sim 3.0$ であることか ら，境界層は層流であるといえる。速度分布は，定温度型熱線流速計(KANOMAX 製 MODEL1010 CTA ANEMOMETER, MODEL1013 LINEARIZER) I 形または X 形熱線プローブ(KANOMAX 製０251R-T5, 0252R-T5) と 3 次元トラバース装置で計測した. 円形ノズル出口の直径は $D_{0}=40 \mathrm{~mm}$ である. テーパ環の肉厚は $2 \mathrm{~mm}$ であ り,テーパ環は厚さ $1 \mathrm{~mm}$ の 4 個のつばによって円形ノズルの中心に固定されている.テーパ環の開き角度は $\alpha= \pm 6^{\circ}$ とし, $\alpha=+6^{\circ}$ の場合を拡大テーパ環(Divergent tapered annulus, Div.), $\alpha=-6^{\circ}$ の場合を縮小テーパ環(Convergent tapered annulus, Conv.) とそれぞれ呼ぶ. 図 2 に示寸ように, 座標の原点は, 円形ノズル出口面と噴流中心軸との交点とし, 原点から流れ方向を $x$ 軸, 半径方向を $r$ 軸として実験を行った.

\section{$2 \cdot 2$ 実験方法}

噴流のレイノルズ数は $\operatorname{Re}\left(=U_{\mathrm{o}} D_{\mathrm{o}} / v, v\right.$ : 空気動粘性係数, $U_{\mathrm{o}}: x / D_{0}=0.1$ 断面の時間平均速度 $) \approx 3.3 \times 10^{4}, 5.0 \times 10^{4}$ として実験を行い，速度分布は円形ノズル直径 $D_{0}$ の 20 倍下流域まで測定した．なお，各テーパ環を設置した場 合の $U_{\mathrm{o}}$ は $x / D_{0}=0.1$ のノズル出口断面における軸方向平均速度分布を積分して体積流量を計算し，テーパ環の有 無にかかわらず体積流量が同じとなるように設定した. 熱線プローブの信号はリニアライザーによって線形化さ れ, A/D 変換ボード(マイクロサイエンス社製 ADM-688PCI)で時間間隔 $100 \mu \mathrm{s}$ とし, 計測点 1 箇所につき 100,000 個のデータをサンプリングした。計測したデータはコンピュータに保存し, 時間平均速度, 乱れ強さなどを算出 した.

流れの可視化は，配管の途中に設置したラスキンノズルによりオイルミストを発生させ，アルゴンイオンレー ザー(Spectra-Physics, Inc.製 4 W) と円筒レンズによってシート光を照射して噴流の $x-r$ 断面をハイスピードビデオ カメラ(PHOTORON 製 FASTCAM SA5)で撮影した。 また, 摺動油(出光興産製 ダフニーマルチウェイ 68C) と酸化チタン(IV)ルチル型の混合液を油膜としてノズル内壁面に塗布し, 噴流を一定速度で5 分間噴出させた後, デジタルカメラ(CANON 製 EOS KISS X5 シャッター速度 1 秒，F36)で油膜の様子を撮影し，剥離の状態を可 視化した.

テーパ環を挿入したことによる圧力損失は, 円形噴流発生装置のチャンバーと周囲流体(大気圧)間の圧力差を 傾斜マノメータによって計測した. チャンバー内整流スクリーンおよび縮流部の圧力損失を予則定し，その損 失を補正することでテーパ環のみの圧力損失を算出した.

\section{$2 \cdot 3$ 実験条件}

実験条件を表 1, 表 2 に示す. 拡大テーパ環 $\left(\alpha=+6^{\circ}\right)$, 縮小テーパ環 $\left(\alpha=-6^{\circ}\right)$ はそれぞれについてテーパ環長さ $L$ $\left(L / D_{\mathrm{o}}=1.0,2.0,3.0\right)$, テーパ環直径 $D_{\mathrm{i} 2}\left(D_{\mathrm{i} 2} / D_{\mathrm{o}}=0.085 \sim 0.72\right)$ を変化させたテーパ環を製作し，実験を行った．テーパ 環の形状による効果は, 非粘性の連続の式から円形ノズル内部でのテーパ環による増減速量を概算することで見 積もることができる．テーパ環の入口と出口の内側断面積をそれぞれ $A_{\mathrm{i} 1}\left(=\pi D_{\mathrm{i} 1}{ }^{2} / 4\right), A_{\mathrm{i} 2}=\left(\pi D_{\mathrm{i} 2}{ }^{2} / 4\right)$ とし，テーパ環 と円形ノズルの間の入口と出口の環状断面積をそれぞれ $A_{01}\left(=\pi\left(D_{0}{ }^{2}-D_{\mathrm{i} 1}{ }^{2}\right) / 4\right), A_{02}\left(=\pi\left(D_{0}{ }^{2}-D_{\mathrm{i} 2}{ }^{2}\right) / 4\right)$ とした. また, 各 テーパ環を区別するために拡大, 縮小テーパ環それぞれについてインデックスを定義し, 拡大テーパ環を D1 D3, D1'〜D3'，縮小テーパ環を $\mathrm{C} 1 \sim \mathrm{C} 3 ， \mathrm{C1}$ 1' C3'とした.

\section{3. 実験結果および考察}

\section{$3 \cdot 1$ 噴流のレイノルズ数依存性およびつばの影響}

図 3 にテーパ環長さ $L / D_{0}=1.0$ の拡大テーパ環 $\left(\alpha=+6^{\circ}\right)$, 縮小テーパ環 $\left(\alpha=-6^{\circ}\right)$ を設置した円形噴流の $R e=3.3 \times 10^{4}$, $R e=5.0 \times 10^{4}$ の場合の軸方向平均速度分布 $\bar{u} / U_{\mathrm{o}}$ を示寸. なお，以下に示寸全ての分布図は見やすいようにプロット 点を適宜間引いてある. 拡大および縮小テーパ環を設置した円形噴流では $R e$ 数が $3.3 \times 10^{4}$ から $5.0 \times 10^{4}$ に変化し てもテーパ環によって形成された速度分布は変化しない. したがって, 本報では $R e=3.3 \times 10^{4}$ の円形噴流の場合に ついて議論する．また，流れ場は噴流の中心軸に対して良好な対称性を示すことがわかる. 
図 4 にテーパ環のつばの影響を見るために, $L / D_{0}=1.0$ の拡大テーパ環におけるつばのない測定断面 1 とつばの 後流となる測定断面 2 で測定した軸方向平均速度分布を示す。つばによって外側噴流の速度分布が影響を受け, ノズル出口で速度が遅くなっているが，内側噴流まではつばの影響を受けないことがわかる． $x / D_{0} \geq 6.0$ ではつば の影響が見られなくなる．本報での実験は全てつばの影響が小さい測定断面 1 での結果を示寸.
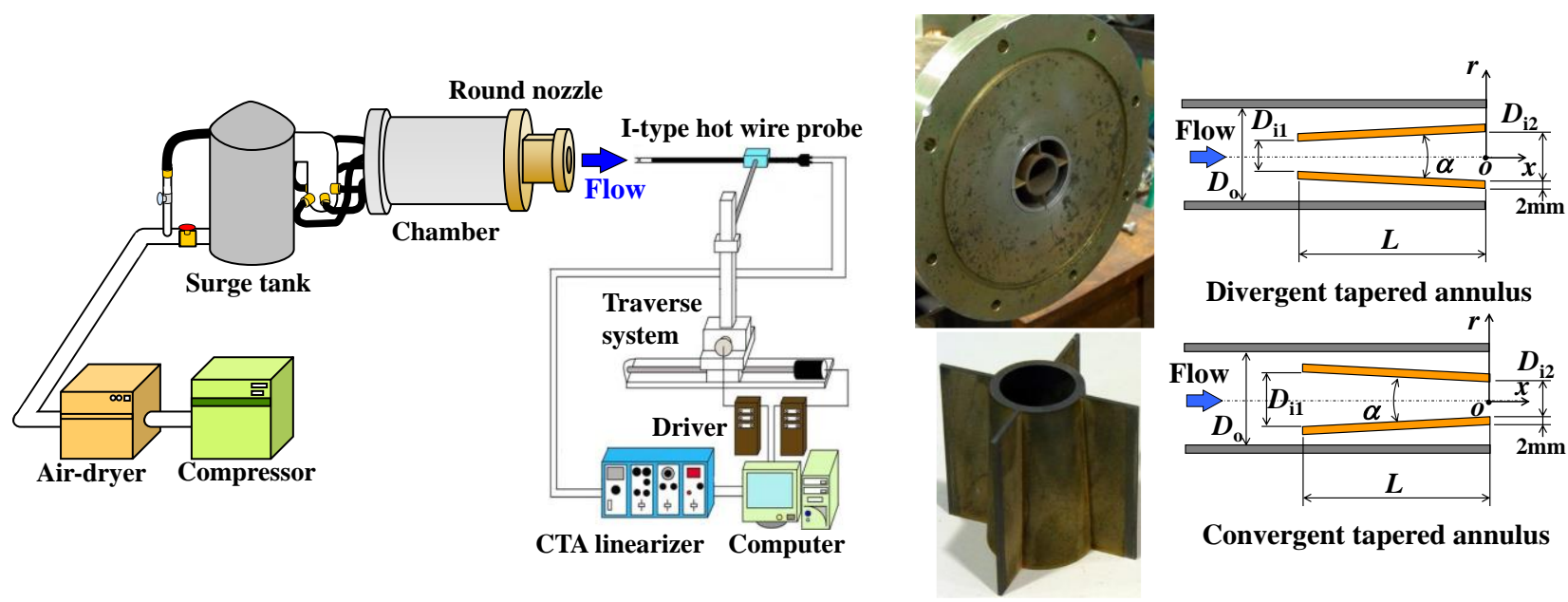

\section{Divergent tapered annulus}

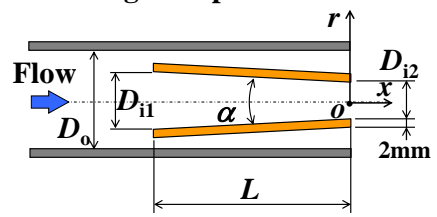

Convergent tapered annulus

Fig.1 Schematic diagram of experimental apparatus. Air compressor is used to supply air flow to the chamber and round nozzle. Round nozzle has a 20.25:1contraction with a diameter and length of $40 \mathrm{~mm}$ and $175 \mathrm{~mm}$.

Table 1 Configuration of divergent tapered annulus

\begin{tabular}{|c|c|c|c|c|c|c|}
\hline Index & D1 & D2 & D3 & D1' & D2' & D3' \\
\hline$L / D_{0}$ & 1.0 & 2.0 & 3.0 & 1.0 & 2.0 & 3.0 \\
\hline$\alpha\left[^{\circ}\right]$ & \multicolumn{6}{|c|}{6} \\
\hline$D_{\mathrm{i} 1} / D_{\mathrm{o}}$ & 0.30 & 0.19 & 0.085 & & 0.4 & \\
\hline$D_{\text {i } 2} / D_{0}$ & \multicolumn{3}{|c|}{0.4} & 0.51 & 0.61 & 0.72 \\
\hline$A_{\mathrm{i} 1} / A_{\mathrm{i} 2}$ & 0.54 & 0.23 & 0.05 & 0.63 & 0.43 & 0.31 \\
\hline
\end{tabular}

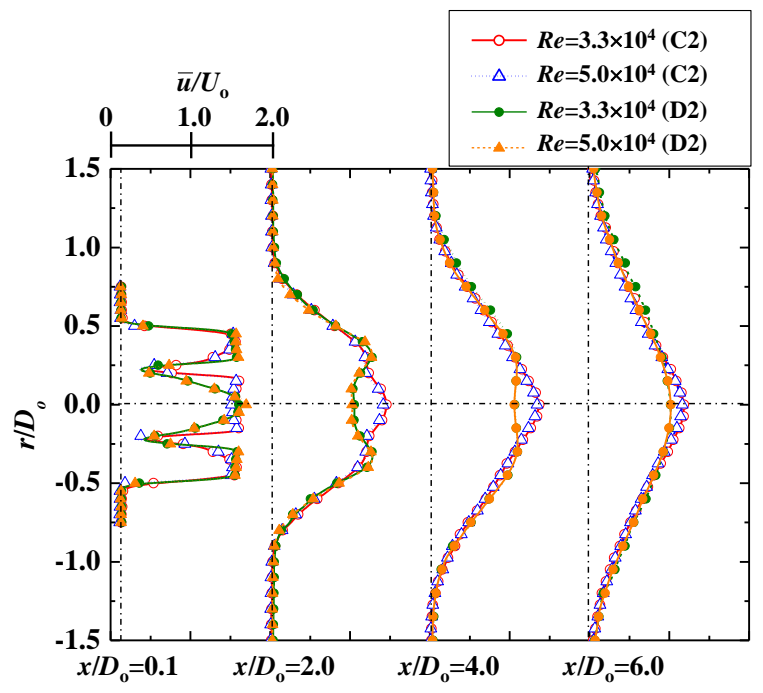

Fig.3 Mean axial velocity profiles in $R e=3.3 \times 10^{4}$ and $5.0 \times 10^{4}$. Velocity profiles in $R e=3.3 \times 10^{4}$ correspond to $R e=5.0 \times 10^{4}$ profiles.
Fig.2 Schematic diagrams and photographs of round nozzle and tapered annulus geometry. $2 \mathrm{~mm}$ thick tapered annulus has 4 flanges to fix to round nozzle. Tapered angle $\alpha$ is $\pm 6^{\circ}$ and length is $L$.

Table 2 Configuration of convergent tapered annulus

\begin{tabular}{|c|c|c|c|c|c|c|}
\hline Index & C1 & C2 & $\mathrm{C3}$ & C1' & C2' & $\mathrm{C3}^{\prime}$ \\
\hline $\bar{L} L / D_{\mathrm{o}}$ & 1.0 & 2.0 & 3.0 & 1.0 & 2.0 & 3.0 \\
\hline$\alpha\left[^{\circ}\right]$ & \multicolumn{6}{|c|}{-6} \\
\hline$D_{\mathrm{i} 1} / D_{0}$ & 0.51 & 0.61 & 0.72 & & 0.4 & \\
\hline$D_{\mathrm{i} 2} / D_{0}$ & \multicolumn{3}{|c|}{0.4} & 0.30 & 0.19 & 0.085 \\
\hline$A_{\mathrm{i} 1} / A_{\mathrm{i} 2}$ & 1.59 & 2.32 & 3.19 & 1.84 & 4.41 & 21.9 \\
\hline
\end{tabular}

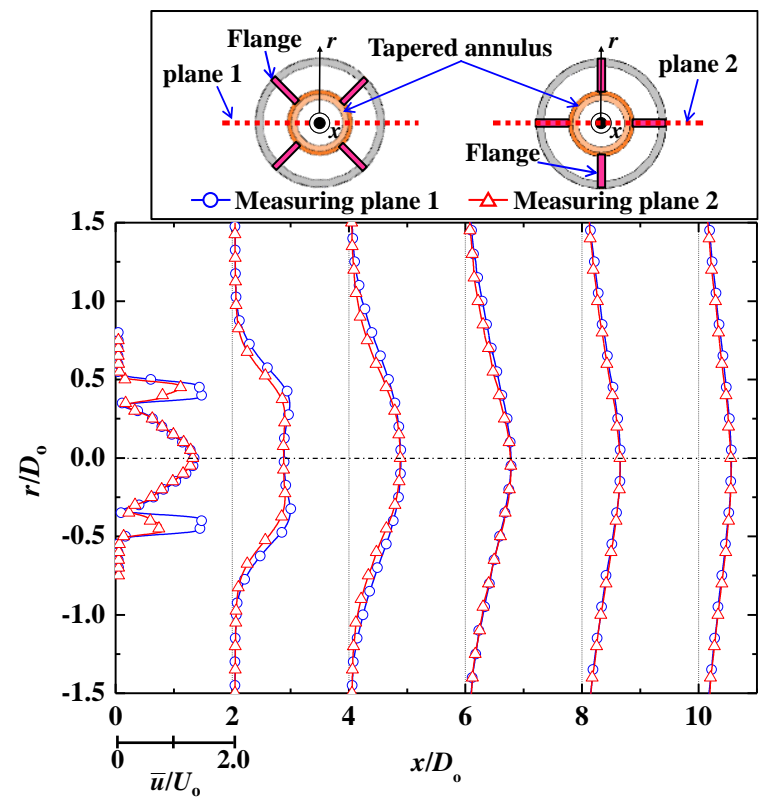

Fig.4 Mean axial velocity profiles of a round jet with divergent tapered annulus (Effect of flanges). There is no influence of flanges on velocity profiles in the downstream of $x / D_{0}=6.0$. 


\section{$3 \cdot 2$ 拡大・縮小テーパ環の影響}

\section{$3 \cdot 2 \cdot 1$ 時間平均速度分布}

図 5 にテーパ環のない円形噴流と，拡大テーパ環，縮小テーパ環，平行環を有する円形噴流の軸方向時間平均 速度分布 $\bar{u} / U_{0}$ をテーパ環長さ $L / D_{0}=2.0$ の場合を例として示す. テーパ環によって円形噴流内には中心軸に対し

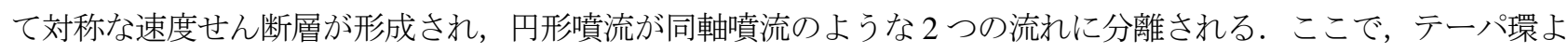
り中心軸側の円形噴流を内側噴流，ノズル壁側の環状噴流を外側噴流と呼ぶ.また，外側噴流の最大速度 $\bar{u}_{\text {omax }}$ に 対する内側噴流の最大速度 $\bar{u}_{\text {imax }}$ の比 $\bar{u}_{\text {imax }} / \bar{u}_{\text {omax }}$ を速度比と定義すると, 拡大テーパ環の場合にはノズル出口 $\left(x / D_{0}=0.1\right)$ で, 外側噴流が増速, 内側噴流が減速し, 速度比は $\bar{u}_{\text {imax }} / \bar{u}_{\text {omax }}=0.53$ となる. $x / D_{0}=1.0 \sim 4.0$ では拡大テーパ 環によって生じた外側噴流よりも速度が遅い内側噴流による速度欠損の領域が下流域まで残る. しかし, $x / D_{0}=5.0$ では噴流中心軸で速度が最大となる分布を呈する，一方，縮小テーパ環の場合には，外側噴流が減速，内側噴流 が増速し, 速度比は $\bar{u}_{\mathrm{imax}} \bar{u}_{\mathrm{omax}}=1.18$ となる.内側噴流にはポテンシャルコアを有しており, $x / D_{0} \geq 4.0$ ではテーパ環 後流の低速部の影響がなくなる.

テーパ環のない円形噴流と $L / D_{0}=3.0$ の拡大テーパ環 $\mathrm{D} 3^{\prime}$ を設置した円形噴流において, $x / D_{0}=10$ 断面での最大速 度 $\bar{u}_{\mathrm{m}}$ と半值幅 $b_{1 / 2}$ で無次元化した軸方向時間平均速度分布を図 6 に示寸. ここで, $L / D_{0}=3.0$ の拡大テーパ環は速 度比が $\bar{u}_{\text {imax }} \bar{u}_{\text {omax }}=0.58$ となることから, 比較のため, Ko ら(Ko and Au, 1981)による同軸噴流 $\left(\bar{u}_{\text {max }} \times \bar{u}_{\text {max }}=0.6\right)$ の速度 分布もプロットした．拡大テーパ環を有する円形噴流は円形噴流や Ko ら(Ko and Au, 1981)の同軸噴流の分布とも ほぼ一致しており，下流では混合・拡散が進み，自己保存流に近づいていることがわかる.

図 7 にテーパ環のない円形噴流と $L / D_{0}=2.0$ の拡大テーパ環, 縮小テーパ環および平行環 $\left(\alpha=0^{\circ}\right)$ を設置した場合 の噴流中心流れ方向の平均速度分布 $\bar{u}_{\mathrm{c}} / U_{\mathrm{o}}$ を示す. また, Sadeghi ら(Sadeghi and Pollard, 2012)による $R e=3.0 \times 10^{4}$ におけるリングのない場合(No ring)とポテンシャルコア内にリングを設置した場合(With ring)の実験結果もあわ せて示す.ここで, 中心軸速度がノズル出口の最大速度の 0.98 倍となる $x$ 方向の位置をポテンシャルコア長さと 定義すると, 円形噴流の場合のポテンシャルコア長さは $x / D_{0}=4.0$, 平行環の場合のポテンシャルコア長さは $x / D_{0}=2.0\left(x / D_{\mathrm{i} 2}=5.0\right)$, 縮小テーパ環の場合のポテンシャルコア長さは $x / D_{0}=3.5\left(x / D_{\mathrm{i} 2}=8.75\right)$ となる. Sadeghi らのリン グを設置しない円形噴流のポテンシャルコア長さは $x / D_{0} \approx 4.0$ となり, 本実験の結果と一致する. また，縮小テー

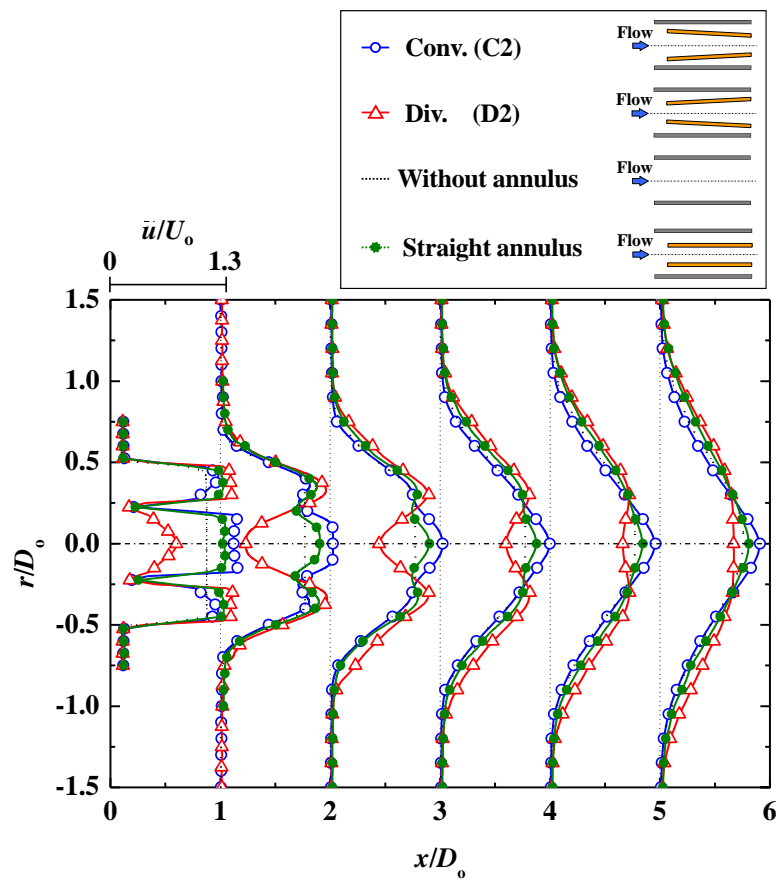

Fig.5 Mean axial velocity profiles of a round jet with convergent and divergent tapered annulus. Round jet is separated into an outer jet and inner jet by annulus.

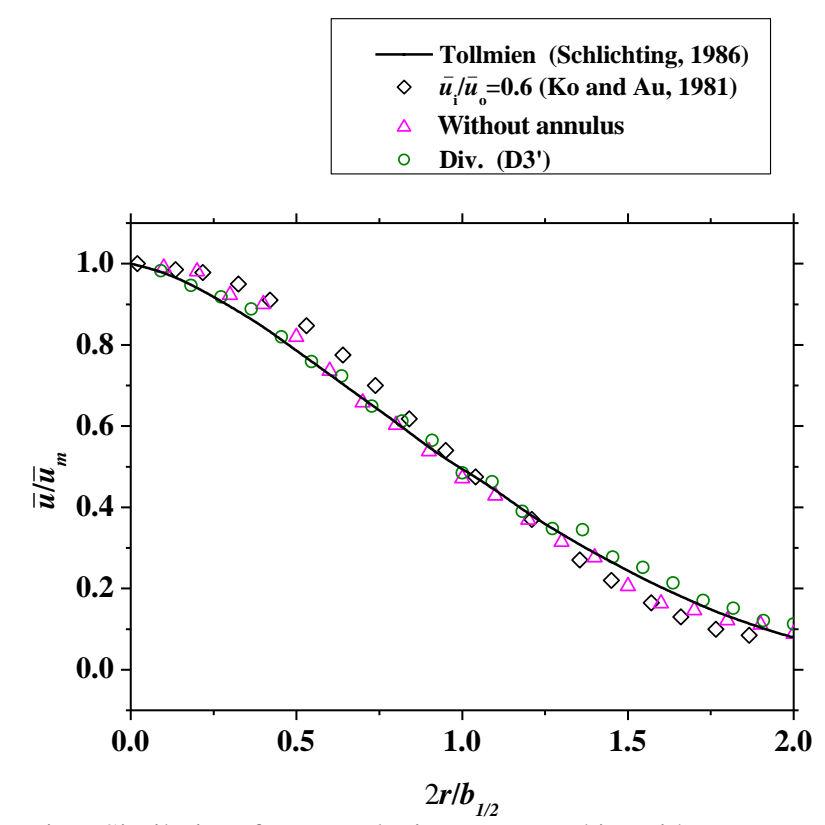

Fig.6 Similarity of mean velocity on a round jet with divergent tapered annulus and without annulus in developed region $\left(x / D_{0}=10\right)$. Velocity profiles of $\mathrm{D}^{\prime}$ corresponds to Tollmien solution and experimental data by Ko and $\mathrm{Au}$ (1981) approximately. 
パ環のポテンシャルコア長さは平行環のポテンシャルコア長さよりも長い. Champagne ら(Champagne and Wygnanski, 1971)は，同軸噴流の内側噴流のポテンシャルコア長さは速度比 1.0 以上の同軸噴流では，外側噴流が あるために内側噴流との間のせん断層が弱められるので， 円形噴流よりも長くなると述べている．この現象は本 研究の縮小テーパ環を捜入した円形噴流でも生じているといえる.一方，拡大テーパ環の場合には内側噴流にポ テンシャルコア領域はなく, 外側噴流にのみ, 長さ $x / D_{0}=1.0$ のポテンシャルコア領域が生じる. 噴流の下流領域 $x / D_{0} \geq 6.0$ では中心軸上速度は発達したいずれの噴流においても円形噴流と同様に減衰する. 下流領域 $\left(x / D_{0}=10 \sim 20\right)$ の中心軸上時間平均速度の減衰勾配を $n$ と寸ると, 拡大テーパ環を設置した場合の中心軸上速度の減衰は, $x / D_{0}$ の-0.94 乗に比例し, 縮小テーパ環の場合は $x / D_{0}$ の-1.06 乗, 平行環の場合は-0.98 乗に比例している. 縮小テー

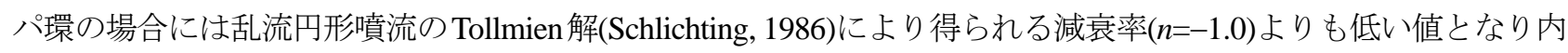
側噴流速度が増速されるために噴流の減衰勾配が大きくなる．拡大テーパ環，平行環の場合に $n$ は Tollmien 解よ りも高い值となり，内側噴流速度が減速されるために噴流の減衰勾配が小さくなる．この現象は偏向板を有する 平面噴流(臼沢他, 2013)でも見られており，10\%程度の減衰勾配の違いが見られた. 同様に Sadeghi ら(Sadeghi and Pollard, 2012)の実験でもテーパ環を設置することで中心軸上速度の減衰率が増加することを報告している.また, 拡大テーパ環の場合は縮小テーパ環と比較して, $x / D_{0}=0.1$ から $x / D_{0}=1.0$ の領域で中心軸上速度が一旦減少し, $x / D_{0}=7.0$ で最大となった後, 再び減少する. $x / D_{0}=0.1 \sim 1.0$ の中心軸上速度の減少は Ko ら(Ko and Au, 1981)の速度 比 0.4 の同軸噴流の実験結果でも示されており, 速度比が小さい同軸噴流の内側噴流は噴出後, 外側噴流に引き 寄せられるため, 噴流断面が拡大し, 中心軸速度が減速すると考えられる. つまり, 同様の効果が拡大テーパ環 を設置した場合にも生じていることが確認できる.

\section{$3 \cdot 2 \cdot 2$ 乱れ強さ分布}

図 8, 9 にテーパ環のない円形噴流とテーパ環長さ $L / D_{0}=2.0$ の拡大テーパ環, 縮小テーパ環および平行環を設 置した円形噴流の軸方向速度変動分布 $u_{\mathrm{rms}}^{\prime} / U_{\mathrm{o}}$ おび半径方向速度変動分布 $v_{\mathrm{rms}}^{\prime} / U_{\mathrm{o}}$ をそれぞれ示す．ノズル出口 $\left(x / D_{0}=0.1\right)$ における軸方向乱れ強さは拡大テーパ環の場合に, 内側噴流と外側噴流の間のせん断層において最大で $u_{\mathrm{rms}}^{\prime} U_{\mathrm{o}} \approx 0.18$ となり, 縮小テーパ環の乱れ強さの約 7 倍になる. 外側噴流と周囲流体との間のせん断層の軸方向 乱れ強さは, 縮小テーパ環の場合に $u_{\mathrm{rms}}^{\prime} / U_{0} \approx 0.11$ となり, 拡大テーパ環の乱れ強さの 3.5 倍になる. 下流の $x / D_{0} \geq 1.0$ では, 拡大テーパ環の場合, 内側噴流と外側噴流の間のせん断層での乱れ強さが減少すると共に, 外側噴流と周 囲流体との間のせん断層で乱れ強さが急激に増加し, 噴流の外側に広がっていく. 一方, 縮小テーパ環の場合, 噴流中心軸付近の乱れ強さが下流に進むにつれて増加すると共に, 外側噴流と周囲流体との間のせん断層におけ る乱れ強さも増加し, この乱れのピーク位置は噴流中心軸側に近づいていく. また, 図 9 に示す半径方向速度変 動分布は，両方のテーパ環において軸方向の速度変動分布と同様な傾向を示す．拡大テーパ環の場合に内側噴流 と外側噴流の間のせん断層内の乱れ強さが縮小テーパ環の場合と比較して増加し， $x / D_{0}=4.0$ の下流まで続く.

図 10 にテーパ環のない円形噴流と拡大テーパ環, 縮小テーパ環および平行環を設置した場合の円形噴流の中心 軸上軸方向速度変動分布 $u_{\mathrm{cms}}^{\prime} / \bar{u}_{\mathrm{c}}$ を示す. $u_{\mathrm{crms}}^{\prime}$ は中心軸上速度 $\bar{u}_{\mathrm{c}}$ で無次元化してある. また, 図 7 と同様に, Sadeghi ら(Sadeghi and Pollard, 2012)の結果はリングを設置しない No ring とリングをポテンシャルコア内に設置した With ring を示寸. 平行環, 縮小テーパ環を設置した場合の中心軸上乱れ強さは円形噴流と同程度の值となり， $x / D_{0}$ の 増加と共に増加し, $u_{\mathrm{crms}}^{\prime} / \bar{u}_{\mathrm{c}}=0.25$ に近づく. 噴流の発達によって $x / D_{0}=20$ より下流では $u_{\mathrm{crms}}^{\prime} / \bar{u}_{\mathrm{c}}=0.25$ に漸近すると 考えられる. 拡大テーパ環の場合には, 図 8 でも分かるようにノズル出口から乱れ強さの值が既に大きく, $x / D_{0}=0.1 \sim 5.0$ で増加, 減少した後再び増加する. ノズル出口近傍での乱れ強さの増加は, 拡大テーパ環内側の剥 離と外側噴流による内側噴流の引き寄せによって生じると考えられる. その後の乱れ強さの変化は流れの発達と ともに他のテーパ環の分布に近づく. $x / D_{0} \geq 7.0$ の乱れ強さは他のテーパ環と同じである. この乱れ強さが増加す る位置は, 図 7 の中心軸上速度が減少する領域と一致し, 拡大テーパ環による流れの乱れによって速度の低下が 生じていることがわかる. Sadeghi らの No ring の乱れ強さは, 本実験の結果よりも值が全体的に大きいことより, 乱れの大きい円形噴流であるといえるが傾向は同じである. With ring の場合には No ring の場合よりも $x / D_{0} \leq 13$ で乱れ強さが小さく, $x / D_{0} \geq 13$ で大きくなる，この傾向は本報の結果では見られず，リングの形状や設置位置の 違いによるものであると考えられる. 


\section{$3 \cdot 2 \cdot 3$ 噴流の広がり}

図 11 にテーパ環のない円形噴流と拡大テーパ環, 縮小テーパ環および平行環を有する円形噴流の半值幅 $b_{1 / 2}$ を ノズル直径 $D_{0}$ で無次元化して示寸. 半值幅は拡大テーパ環の場合にノズル出口から急激に大きくなり，全領域で テーパ環のない円形噴流よりも大きい。一方，縮小テーパ環の場合には半值幅はノズル出口から若干減少し，テ 一パ環のない円形噴流よりも小さくなる。したがって，拡大テーパ環ではノズル出口から噴流は広がり，縮小テ 一パ環では広がらないことがわかる．また，平行環の場合には円形噴流と同程度の広がりを示す，テーパ環の拡 大, 縮小, 平行である条件が噴流の広がり方に及ぼす影響は, 前報(臼沢他, 2013)の平面噴流の場合と同じである.

\section{$3 \cdot 2 \cdot 4$ 噴流の可視化}

図 12 に拡大テーパ環および縮小テーパ環表面の剥離状態を見るために行った油膜法による可視化結果を示す. 拡大テーパ環では，外側噴流側のテーパ環外側表面に剥離が生じていない(図 a-1)。また，内側噴流側のテーパ環 内側表面の上流部では油膜が残っていることより，剥離が生じていると考えられる(図 a-3)。これより，内側噴流 はテーパ環入口端で一旦剥離した後，テーパ環内側表面に再付着し，拡大テーパ環によって拡大されると考えら れる.一方, 縮小テーパ環では, 内側噴流側の縮小テーパ環内側表面で流れの剥離が生じていない(図 b-3). また, 外側噴流側の縮小テーパ環外側表面の上流部 $\left(x / D_{0}=-1.8 \sim-2.0\right) て ゙$ 油膜が残っており, 剥離が生じている(図 b-2). 外 側噴流は縮小テーパ環入口端で剥離した後, 壁面に再付着し, 拡大される.したがって, 図 8, 図 9 で示したノ ズル出口 $\left(x / D_{0}=0.1\right)$ において拡大テーパ環では内側噴流で乱れが大きくなり，縮小テーパ環では外側噴流で乱れが 大きくなる現象は，テーパ環入口付近の剥離と再付着後の流れの拡大によって生じていると考えられる.

図 13 にテーパ環のない円形噴流，拡大テーパ環，縮小テーパ環および平行環を設置した場合のミス卜法による 可視化画像をそれぞれ示す. 図 13(a)には，10.75 秒間の可視化動画の全 215 フレームの静止画像を平均化処理し た時間平均による画像を示す. 図 13(b)には瞬間の画像を示す。時間平均画像より, 平行環を有する円形噴流はテ 一パ環を設置しない場合と比較して,$x / D_{0}=2.0$ 付近から噴流の広がりが大きくなる．瞬間の画像を見ると，平行
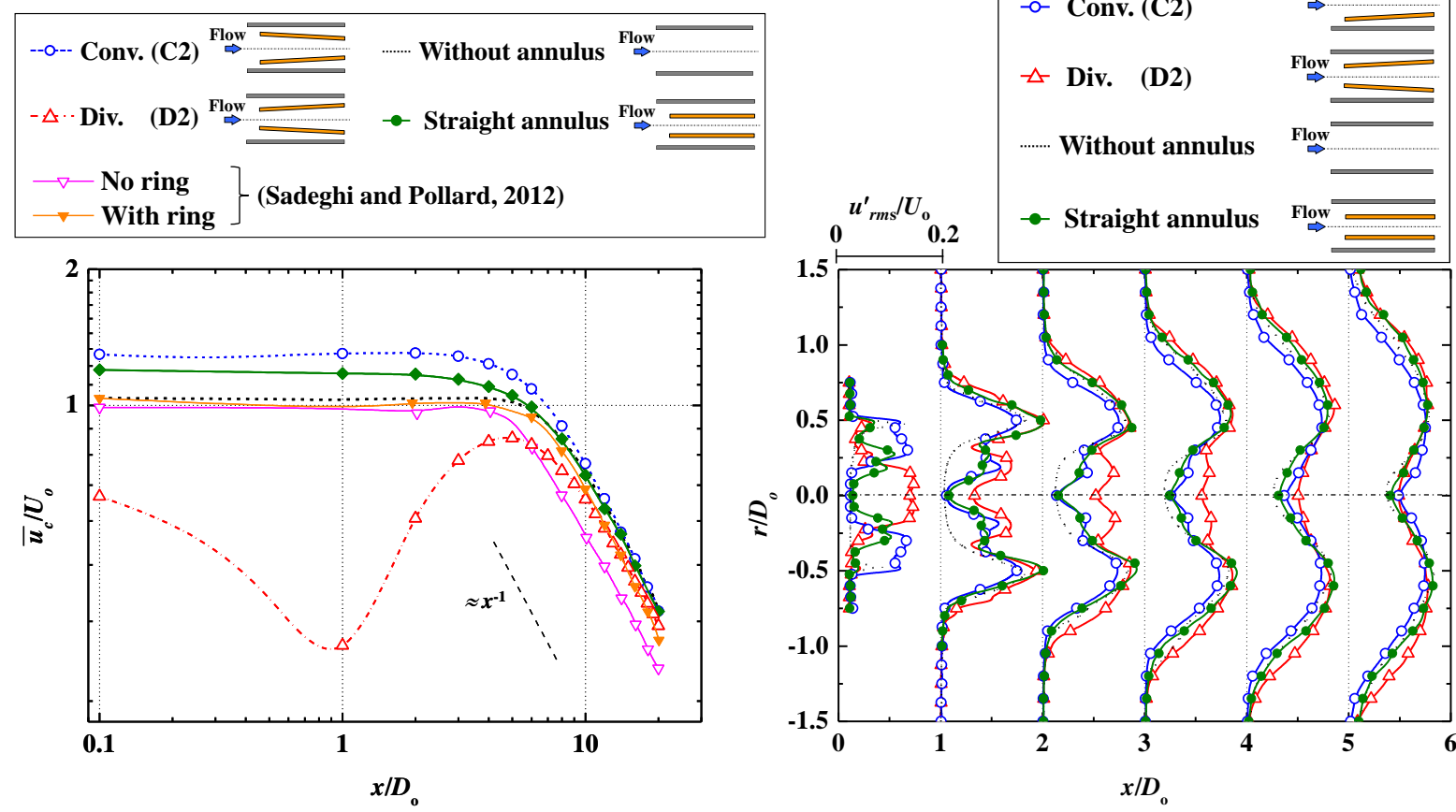

Fig.7 Mean axial velocity profiles along the centerline of a round jet with convergent and divergent tapered annulus. A length of potential core and attenuation rate $n$ correspond to experimental data by Sadeghi and Pollard (2012).

Fig.8 Axial velocity fluctuation profiles of a round jet with convergent and divergent tapered annulus. With divergent annulus, velocity fluctuation increased at shear layer between outer jet and ambient fluid rapidly. With convergent annulus, velocity fluctuation increased at center of jet and shear layer between outer jet and ambient fluid. 
環の場合にはテーパ環の厚さによる後縁からの後流によって内側噴流と外側噴流の間のせん断層内に渦列が生じ ており， $x / D_{0} \geq 2.0$ で噴流全体が乱れているように見える．拡大テーパ環の場合には，時間平均画像を見ると他の テーパ環よりも噴流が $x / D_{0}>2.0$ で外側に広がっていることがわかる. 瞬間の画像では, 内側噴流の下流で乱れが 大きくなり，噴流の全体でノズル出口から既に流れが乱れている様子が可視化からもわかる．一方，縮小テーパ 環の場合には，時間平均画像より他のテーパ環よりも噴流の広がりが小さい．瞬間の画像を見ると内側噴流内の ミストは $x / D_{0}=2.0$ 付近まで筋状になっており, 乱れの小さい領域が下流域で生じているが，外側噴流の下流では 筋状の流れパターンは見られず，流れが乱れている.

\section{$3 \cdot 3$ テーパ環長さによる影響}

テーパ環直径を $D_{\mathrm{i} 2} / D_{0}=0.4$ に固定してテーパ環長さ $L / D_{0}$ を変化させた場合の拡大, 縮小テーパ環を有する円形 噴流の軸方向平均速度分布 $\bar{u} / U_{0}$ を図 14 の上下にそれぞれ示す. なお，図中にはテーパ環のない円形噴流の速度分 布も示してある. 図 14 の上側に示寸縮小テーパ環ではテーパ環長さが $L / D_{0}=1.0$ から 3.0 に増加すると, $x / D_{0}=0.1$ における内側噴流の最大軸方向平均速度は $1.5 U_{0}$ に増加寸る一方, 外側噴流の最大軸方向平均速度は 0.88 倍に減 少する.これは，テーパ環が長い場合には，外側噴流のテーパ環入口側の断面積が小さくなる一方で内側噴流の テーパ環入口側の断面積が大きくなったためである.下流では，内側噴流と外側噴流の間のせん断層の速度欠損 が回復し, $x / D_{0} \geq 3.0$ の領域において発達した速度分布となる. 図 14 の下側に示寸拡大テーパ環の場合, 軸方向平 均速度分布はノズル出口 $\left(x / D_{0}=0.1\right)$ においてテーパ環長さが $L / D_{0}=3.0$ に増加すると外側噴流で増速し, 内側噴流で 減速し, 速度比は $L / D_{0}=1.0$ で $\bar{u}_{\text {imax }} \bar{u}_{\text {omax }}=1.0, L / D_{0}=3.0$ で $\bar{u}_{\text {imax }} \bar{u}_{\text {omax }}=0.10$ となる.

図 15 にテーパ環のない場合, 拡大テーパ環および縮小テーパ環がある場合の軸方向速度変動分布 $u_{\mathrm{rms}}^{\prime} / U_{\mathrm{o}}$ をそ れぞれ示す. 図 15 の上側に示す縮小テーパ環では, テーパ環長さが $L / D_{0}=1.0$ から 3.0 に変化すると $x / D_{0}=0.1$ で は, 乱れ強さの值が小さくなるが, $x / D_{0} \geq 1.0$ の下流では内側噴流と外側噴流の間のせん断層で乱れ強さが増加し, 下流に流れるにしたがって速度分布が発達するにつれて増加する. 一方, 図 15 の下側に示寸拡大テーパ環では,
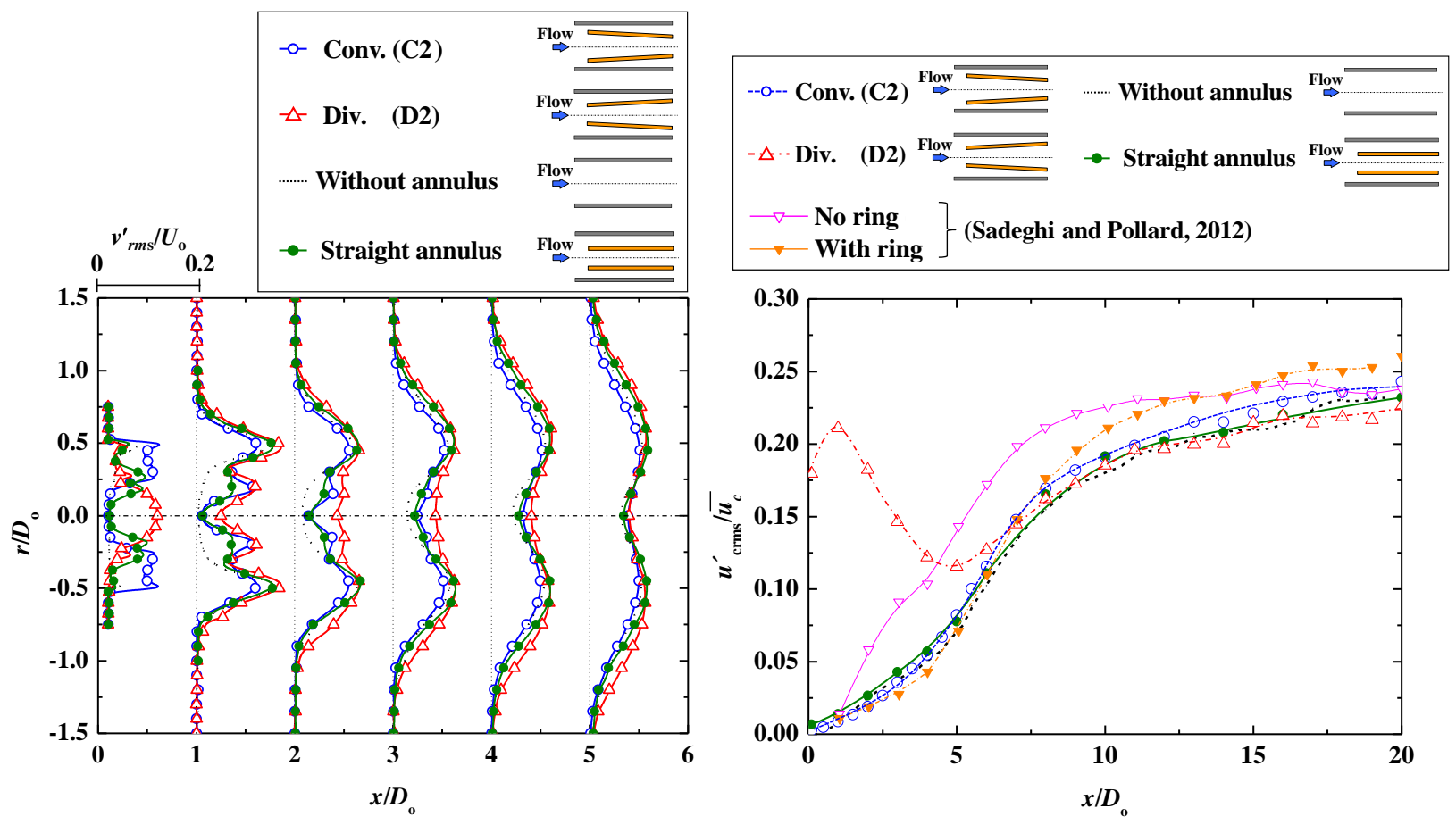

Fig.9 Radial velocity fluctuation profiles of a round jet with convergent and divergent tapered annulus. Development of the radial velocity fluctuation profiles is similar to that of the axial velocity fluctuation profiles.
Fig.10 Axial velocity fluctuation along the centerline of a round jet with convergent and divergent tapered annulus. With divergent annulus, velocity fluctuation along the centerline increased at nozzle exit rapidly. With convergent annulus, variation of the velocity fluctuation profiles along the centerline are the same as the velocity fluctuation profiles with straight and without annulus. 
$x / D_{0}=0.1$ で乱れ強さは減少するが， $x / D_{0} \geq 1.0$ の下流では周囲流体と外側噴流のせん断層および外側噴流と内側噴 流の間のせん断層で増加する. 特に, $x / D_{0}=2.0 \sim 3.0$ では速度分布より明らかなように内側噴流と外側噴流の混合 に伴って乱れ強さが著しく増加する。

図 16 にテーパ環長さを変化させた場合の各噴流の半值幅 $b_{1 / 2} / D_{0}$ の $x$ 軸方向変化を示す．半值幅は $L / D_{0}=3.0$ の 縮小テーパ環の場合にテーパ環のない円形噴流よりも減少し，拡大テーパ環の場合にテーパ環のない円形噴流よ りも増加する．したがって，比較的長い縮小テーパ環を円形ノズル内に設置することで円形噴流の広がりを抑制 することが可能となる. これは, $L / D_{0}=3.0$ の縮小テーパ環を設置することで図 14 に示すようにノズル出口におい て内側噴流が増速されるのに対して外側噴流が減速するため, 周囲流体との速度勾配が緩くなるためであると考 えられる.一方, 拡大テーパ環の場合は内側噴流が減速されるのに対して, 外側噴流が増速するため, 外側噴流 と周囲流体の速度差が大きくなる，そのため，外側噴流と周囲流体の間のせん断層の乱れ強さが増加するととも に, エントレイメントも増加することで, 噴流幅がノズル出口に近い位置から広がると考えられる. この傾向は, 平面噴流(臼沢他, 2013)でも確認された.

\section{$3 \cdot 4$ テーパ環直径による影響}

テーパ環長さを $L / D_{0}=2.0$, 角度を $\alpha= \pm 6^{\circ}$ に固定して拡大テーパ環および縮小テーパ環の出口直径を $D_{\mathrm{i} 2} / D_{0}=0.61$ から 0.4 に変化させた場合の軸方向平均速度分布 $\bar{u} / U_{\mathrm{o}}$ を図 17 の上側に, 軸方向速度の乱れ強さ分布 $u_{\mathrm{rms}}^{\prime} U_{\mathrm{o}}$ を図 17 の下側にそれぞれ示す. 図 17(a)に示す拡大テーパ環の軸方向平均速度分布は, ノズル出口近傍 $\left(x / D_{0}=0.1\right)$ でテ
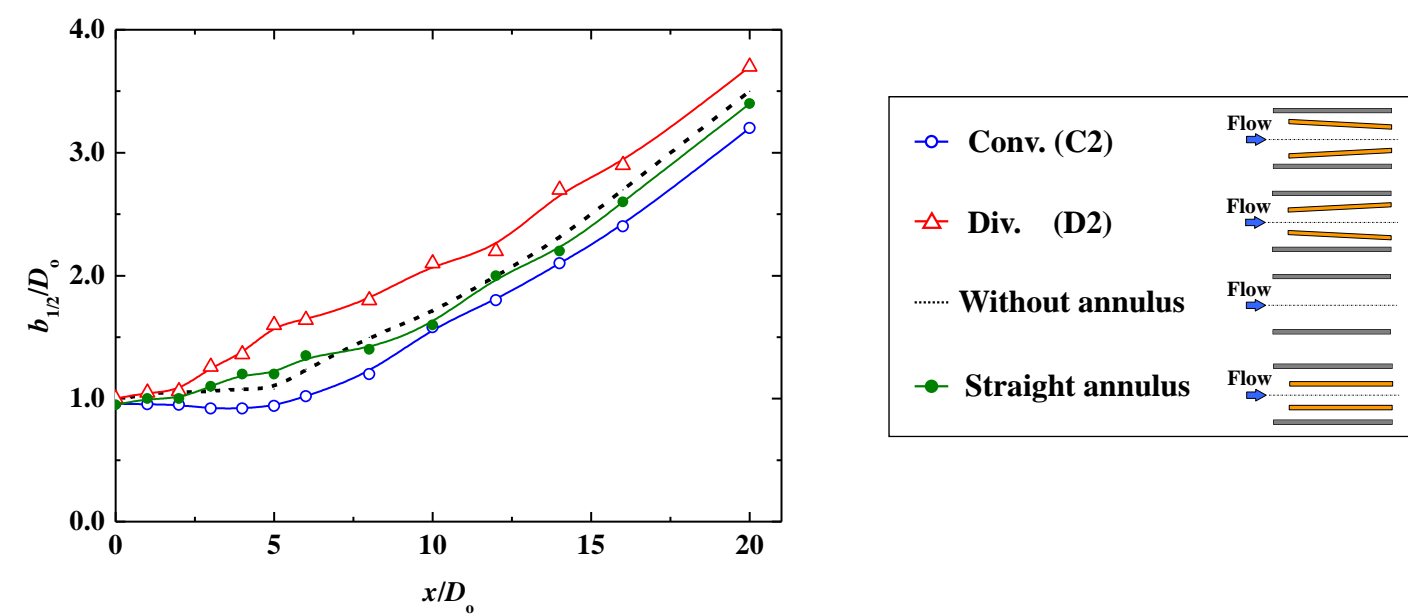

Fig.11 Half-width of a round jet with convergent and divergent tapered annulus. With convergent annulus, half-width was decreased and with divergent annulus, half-width was increased compared with the without annulus.

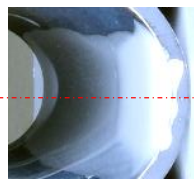

$\mathrm{a}-3$

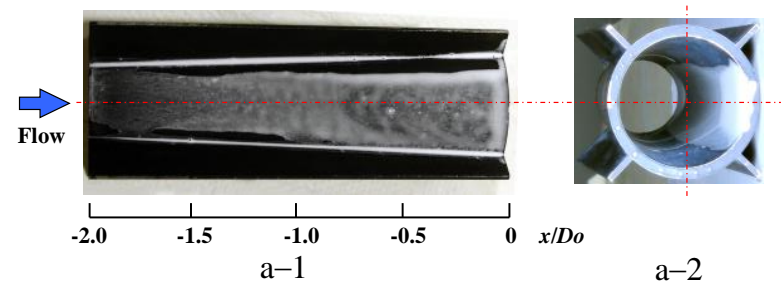

(a) Divergent tapered annulus (D2')

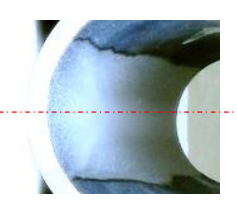

b-3

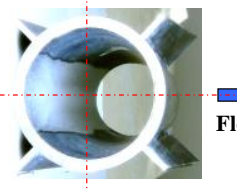

b-1

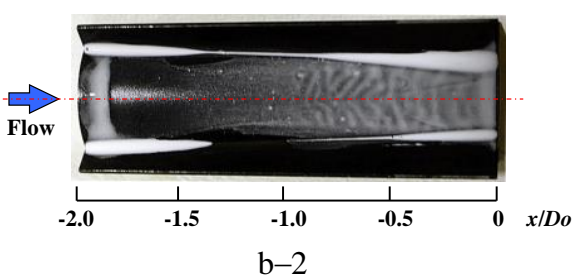

(b) Convergent tapered annulus (C2)

Fig.12 Flow visualization on the surface of the convergent and divergent tapered annulus by the oil-film method. With divergent annulus, fig.12 (a) shows separated flow in the inner surface of annulus. With convergent annulus, fig.12 (b) shows separated flow in the outer surface of annulus. 
一パ環直径が $D_{\mathrm{i} 2} / D_{0}=0.61$ から 0.4 に小さくなると内側噴流の流量が減少し，軸方向速度が小さくなるため速度比 $\bar{u}_{\text {imax }} \bar{u}_{\text {omax }}$ が増加する. 直径の減少によって内側噴流の軸方向速度が減少寸ることで内側噴流と外側噴流の間のせ 儿断層における乱れ強さも共に減少する. 下流では, 拡大テーパ環直径が小さい場合 $\left(D_{\mathrm{i} 2} / D_{0}=0.4, \mathrm{D} 2\right)$ に, 噴流中 心軸付近での速度欠損の回復が遅れ， $x / D_{0}=4.0$ で回復し同程度となる. 乱れ強さ分布は, $x / D_{0}=1.0$ において $D_{\mathrm{i} 2} / D_{0}=0.61$ の場合に $r / D_{0}< \pm 0.4$ で $u_{\mathrm{rms}}^{\prime} / U_{0}=0.18 \sim 0.15$ となるのに対して, $D_{\mathrm{i} 2} / D_{0}=0.4$ の場合には周囲流体と外側噴流 との間のせん断層および内側噴流と外側噴流との間のせん断層の両方で高くなり, それ以外の領域では乱れ強さ は小さいままである.また， $x / D_{0}>4.0$ では出口直径による違いがみられなくなり，噴流の混合が進んでいること がわかる.

一方, 図 17(b)の縮小テーパ環の場合には, 拡大テーパ環と同様にテーパ環直径が $D_{\mathrm{i} 2} / D_{0}=0.4$ から 0.19 にさく なるとノズル出口近傍 $\left(x / D_{0}=0.1\right)$ で内側噴流の流量が減少し, 軸方向速度が小さくなるため速度比 $\bar{u}_{\text {imax }} / \bar{u}_{\text {omax }}$ は減少 する. ノズル出口近傍 $\left(x / D_{0}=0.1\right)$ では, テーパ環直径が小さくなると, 内側噴流と外側噴流の間のせん断層で乱れ 強さは僅かに増加する. 下流では, 縮小テーパ環直径が小さい場合 $\left(D_{\mathrm{i} 2} / D_{0}=0.19, \mathrm{C} 2^{\prime}\right)$ に噴流中心軸付近の速度の回 復が遅れ，噴流中心部の乱れ強さが高くなるが，それ以外に乱れ強さの分布には大きな違いは見られない.
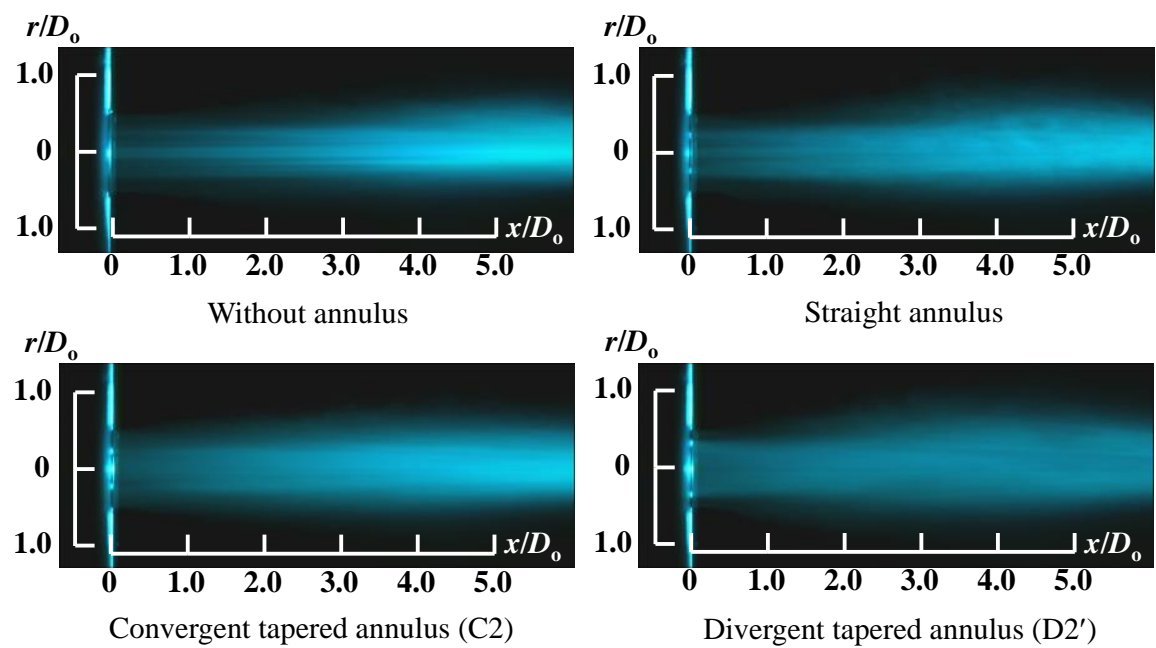

(a) Time-averaged photographs
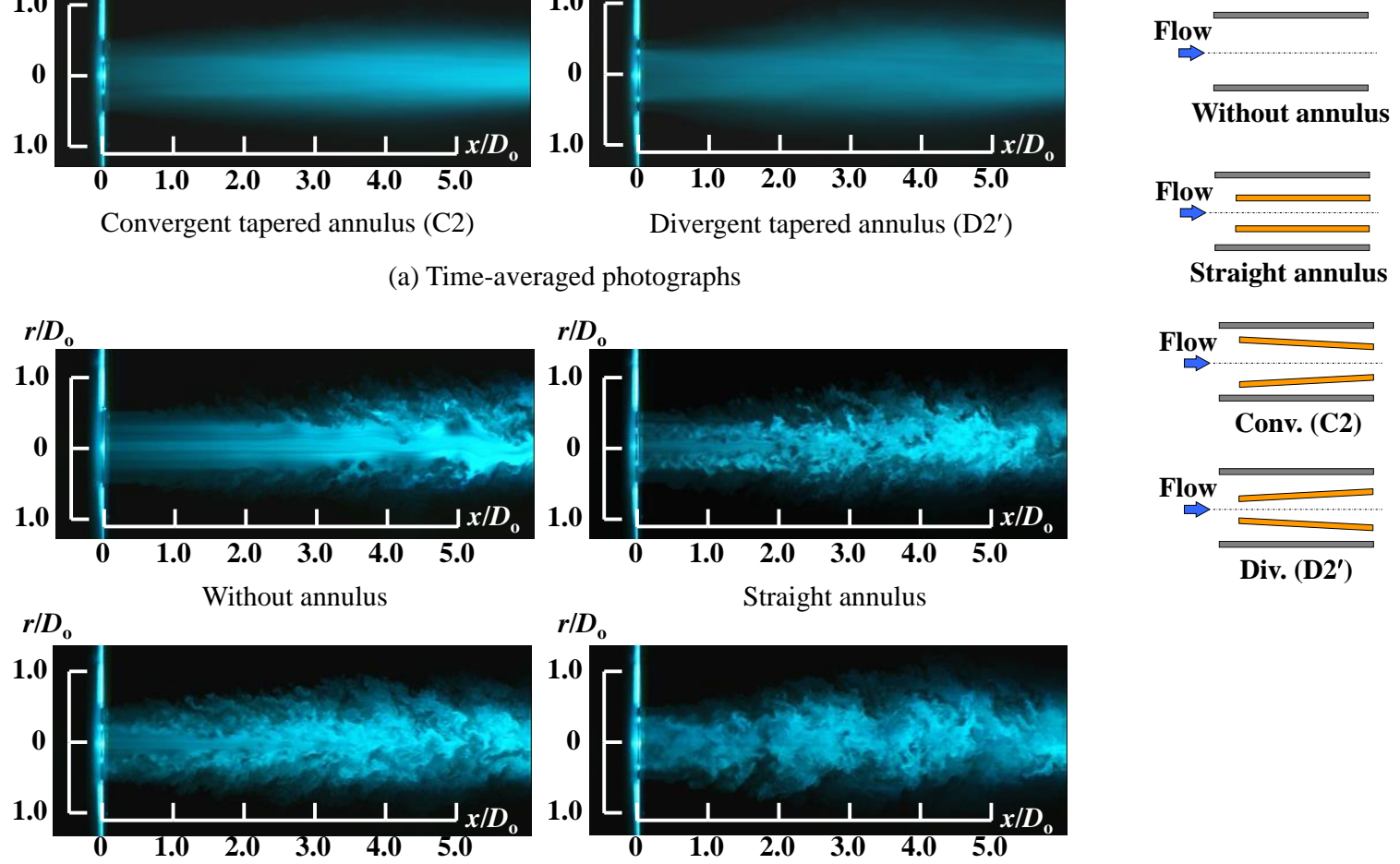

Convergent tapered annulus (C2)

Divergent tapered annulus (D2')

(b) Instantaneous photographs

Fig.13 Flow visualizations of a round jet with straight annulus, convergent tapered annulus, divergent tapered annulus and without annulus. Spread of round jet with divergent tapered annulus increased compared with other annulus. Spread of round jet with convergent tapered annulus decreased compared with other annulus. Inner jet of round jet with divergent tapered annulus had small-scale vortices near the center of the jet. 
図 18 に拡大および縮小テーパ環直径 $D_{\mathrm{i} 2} / D_{0}$ の変化による中心軸上の軸方向時間平均速度分布 $\bar{u}_{\mathrm{c}} / U_{\mathrm{o}}$ を示寸．拡 大テーパ環の直径の小さい $D_{\mathrm{i} 2} / D_{0}=0.4$ の拡大テーパ環(D2)では中心軸速度は $x / D_{0}=1.0$ で極小值を示し, 再び急激

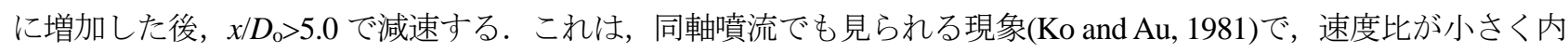
側噴流速度が小さい場合には，外側噴流へのエントレイメントのためにノズル出口近傍で急激な中心軸上速度の 減少が生じる．下流 $\left(x / D_{0}>1.0\right)$ では外側噴流と内側噴流の混合が進み，中心軸速度は回復寸る．一方，他のテーパ 環(C2, C2', D2')では中心軸速度は徐々に減少する. 縮小テーパ環の場合は, $D_{\mathrm{i} 2} / D_{0}=0.4$ から 0.19 の直径の減少によ って拡大テーパ環と同様に中心軸速度は減少するが，拡大テーパ環ほどの減少は見られない。ここで，拡大テー パ環の D2' と縮小テーパ環 C2'の分布がよく類似していることがわかる．これは 4 種類のテーパ環 C2, C2'， D2， D2'のうち C2'と D2'の速度比が比較的近いためであると考えられる. 図 19 に拡大および縮小テーパ環直径を同様 に変化させた場合の半值幅 $b_{1 / 2} / D_{0}$ の分布を示寸. 拡大テーパ環の場合に, 半值幅は $D_{\mathrm{i} 2} / D_{0}$ が 0.61 から 0.4 に減少

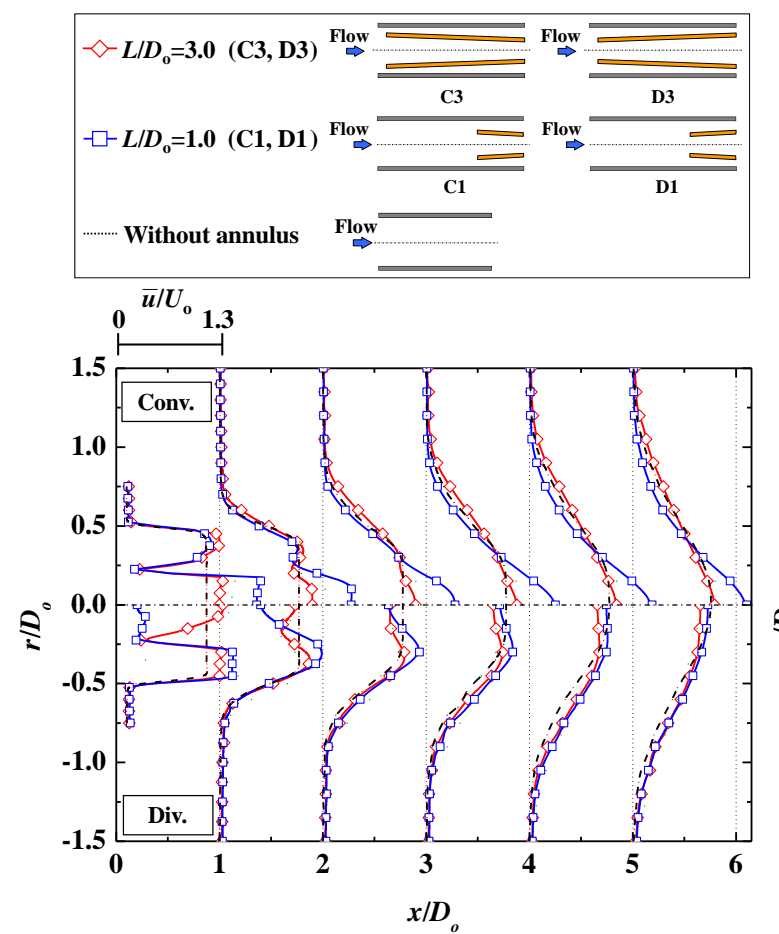

Fig.14 Mean axial velocity profiles of a round jet with convergent and divergent tapered annulus (Effect of length). Inner jet of round jet with convergent annulus of $L / D_{0}=3.0$ was accelerated. Outer jet of round jet with divergent annulus of $L / D_{0}=3.0$ was accelerated.

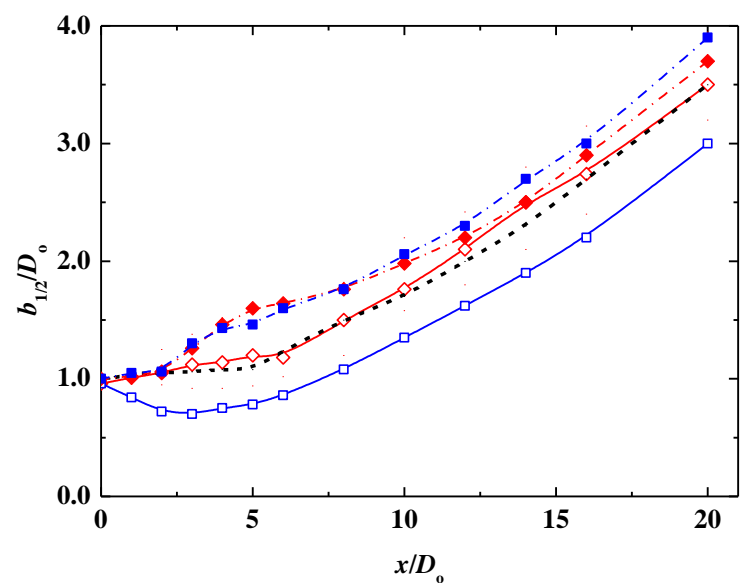

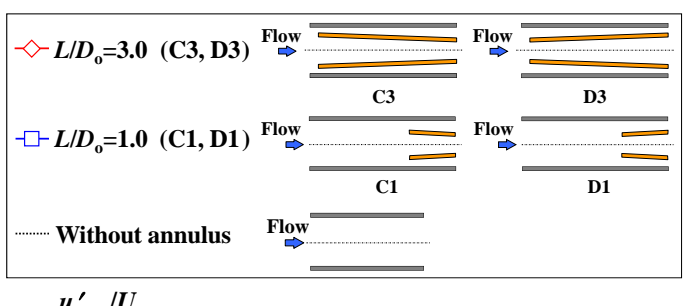

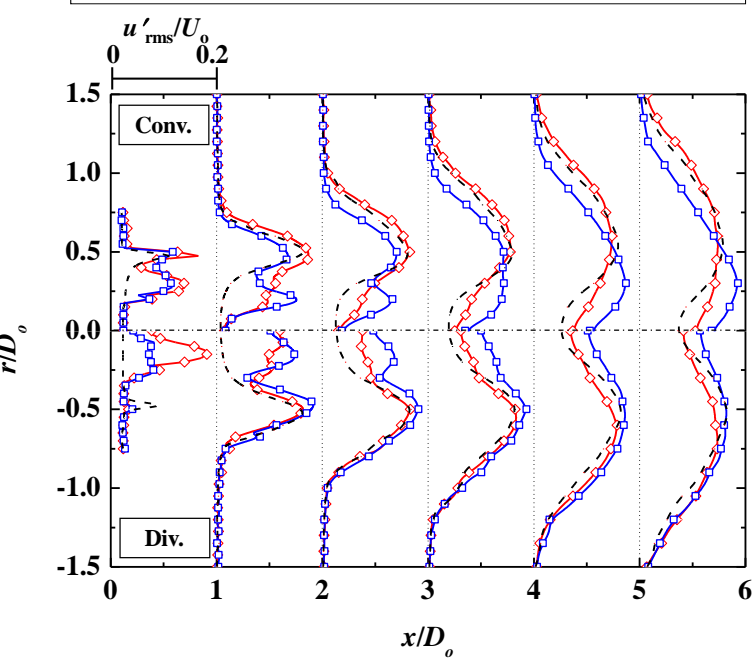

Fig.15 Axial velocity fluctuation profiles of a round jet with convergent and divergent tapered annulus (Effect of length). Velocity fluctuation profiles of round jet with convergent and divergent annulus of $L / D_{0}=3.0$ was increased at shear layer between inner and outer jet.

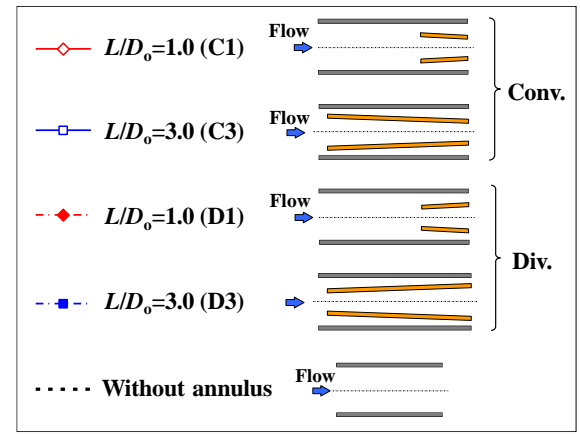

Fig.16 Half-width of a round jet with convergent and divergent tapered annulus (Effect of length). Half-width of round jet with convergent annulus of $L / D_{0}=3.0$ decreased compared with $L / D_{0}=1.0$ convergent annulus. With divergent annulus of $L / D_{0}=3.0$, half-width increased compared with $L / D_{0}=1.0$ divergent annulus. 
するに伴って，ノズル出口近傍と噴流の下流域において $x / D_{0}=7.5$ 付近を境にして減少することがわかる. 一方， 縮小テーパ環の場合は, 拡大テーパ環とは逆の傾向を示し， $D_{\mathrm{i} 2} / D_{0}$ が 0.4 から 0.19 に減少すると，ノズル出口近 傍と噴流の下流域において $x / D_{0}=7.5$ 付近を境にして半值幅は増加する.

\section{$3 \cdot 5 \quad$ テーパ環形状が噴流の流れ特性に与える影響}

表 3, 表 4 に拡大，縮小テーパ環の内側噴流，外側噴流の面積比 $A_{\mathrm{i} 1} / A_{\mathrm{i} 2}, A_{02} / A_{01}$ と長さ $L / D_{0}$, 直径 $D_{\mathrm{i} 2} / D_{0}$, 速度 比 $\bar{u}_{\text {imax }} \bar{u}_{\text {omax }}$ の関係をまとめたものを示す. 図 20 にテーパ環の長さ $L / D_{0}$ および直径 $D_{\mathrm{i} 2} / D_{0}$ の変化による面積比, つまり拡大テーパ環の場合をテーパ環内側の入口と出口の面積比 $A_{\mathrm{i} 1} / A_{\mathrm{i} 2}$, 縮小テーパ環の場合をテーパ環外側の 出口と入口の面積比 $A_{02} / A_{01}$ に対する噴流の速度比 $\bar{u}_{\text {max }} / \bar{u}_{\text {max }}$ の変化を示す．なお，赤色の菱形白抜きプロットでテ 一パ環直径 $D_{\mathrm{i} 2} / D_{0}$ による変化を示し，赤色の四角形プロットでテーパ環の長さ $L / D_{0}$ による変化を示す．また，比 較のため, 偏向板を有する平面噴流の偏向板長さを変化させた実験結果(臼沢他, 2013)についても青色のプロット で示す. 図 20 より，縮小テーパ環の場合，テーパ環によってテーパ環内側の流路断面積が減少し，内側噴流の速 度が増加して, 速度比 $\bar{u}_{\text {imax }} \bar{u}_{\text {omax }}$ は 1.0 以上となる. つまり, 平面噴流と同様に, C1 C3 のプロットを見ると縮小 テーパ環長さの増加は面積比 $A_{02} / A_{01}$ を増加させることで速度比が増加することになる. C1' C3'の場合, C1 C3 と比較すると同じ縮小テーパ環長さでテーパ環直径 $D_{\mathrm{i} 2}$ を減少させたとき $\left(\mathrm{C1}^{\prime} \sim \mathrm{C} 3^{\prime}\right)$ にはテーパ環内側の面積比 $A_{02} / A_{01}$ と速度比の変化はほとんどない，これは，テーパ環直径を小さくすることで，内側噴流に流入する流量が 減少し，縮小テーパ環による内側噴流の増速作用が相殺されるためである，一方，拡大テーパ環の場合，テーパ 環外側の流路面積が減少し, 外側噴流の速度が増加するため, 速度比 $\bar{u}_{\text {imax }} \bar{u}_{\text {omax }}$ は 1.0 以下となる. D1 D3 のプロ ットを見ると拡大テーパ環長さの増加は面積比 $A_{\mathrm{i} 1} / A_{\mathrm{i} 2}$ を減少して, 速度比 $\bar{u}_{\mathrm{imax}} / \bar{u}_{\text {omax }}$ が減少することになる. D1' D3'と D1 D3 を比較すると同じ拡大テーパ環長さでテーパ環直径 $D_{\mathrm{i} 2}$ を減少させたとき(D1 D3)にはテーパ環 内側の面積比 $A_{\mathrm{i} 1} / A_{\mathrm{i} 2}$ の増加と共に速度比 $\bar{u}_{\mathrm{imax}} / \bar{u}_{\mathrm{omax}}$ が増加する. これは, 内側噴流の直径が小さくなることで内側 噴流の流速が減少した分が外側噴流に流れ，外側噴流の流速が増加するためである．つまり，拡大テーパ環の外 側噴流の増速効果と内側噴流の減速作用が一緒に作用して, 結果的に速度比が 1 に近づくと考えられる. また, 平面噴流と比較すると，テーパ環と偏向板形状の違いによる差はあるが，速度比に対する面積比の变化は拡大偏 向板，縮小偏向板の両方で傾向が一致することが明らかとなった.

図 21 に図 20 と同様なテーパ環の形状変更による圧力損失係数 $\zeta_{u \max }\left(=2 \Delta p /\left(\rho u_{\max }{ }^{2}\right)\right)$ と速度比 $\bar{u}_{\text {max }} \bar{u}_{\text {omax }}$ の関係を 示す. 縮小テーパ環の場合, テーパ環長さ, 直径を変化させると速度比の増加と共に圧力損失係数 る. C1' C3'の場合, C1 C3 と比較すると同じ縮小テーパ環長さでテーパ環直径を小さくした場合 $\left(\mathrm{C1}^{\prime} \sim \mathrm{C} 3^{\prime}\right) に は$, 圧力損失係数 $\zeta_{\text {umax }}$ は 1.1 1.3 と増加するが, 速度比 $\bar{u}_{\text {imax }} / \bar{u}_{\text {omax }}$ はほとんど変化しない. 一方, 拡大テーパ環の場合 には，テーパ環長さ，直径を変化させて速度比が減少すると圧力損失は逆に大きくなる．D1' D ${ }^{\prime}$ と D1 D3 を比 較すると同じ拡大テーパ環長さでテーパ環直径を小さくしたとき(D1 D3)には, 圧力損失係数 $\zeta_{u \text { max }}$ は 1.0 1.4 と 大きくなる．したがって，拡大，縮小テーパ環を設置することで速度比を $0.1 \sim 1.6$ に変化させることが可能であ るが, $\bar{u}_{\text {max }} \bar{u}_{\text {max }}$ が1.0から離れた值になると圧力損失が増加する. 寸なわち, 速度比を変化させるという観点から 見ると，テーパ環直径よりもテーパ環長さを変化させた方が圧力損失が少ないことがわかる．また，平面噴流と 比較すると, 圧力損失係数はノズル形状の違いから円形噴流よりも全体的に小さいが, 速度比の変化による圧力 損失係数の増加の傾きはほぼ一致する.

図 22 にテーパ環なし，拡大テーパ環，縮小テーパ環における拡散率 $K_{\mathrm{y}}$ と速度比の関係を示寸. 拡散率 $K_{\mathrm{y}}$ は流 れ方向の距離 $x / D_{0}$ に対する半值半幅 $b_{1 / 2} / 2$ の勾配であり, 式(1)で定義される.

$$
\frac{b_{1 / 2}}{2 D_{o}}=K_{y}\left(\frac{x}{D_{o}}-\frac{x_{o}}{D_{o}}\right)
$$




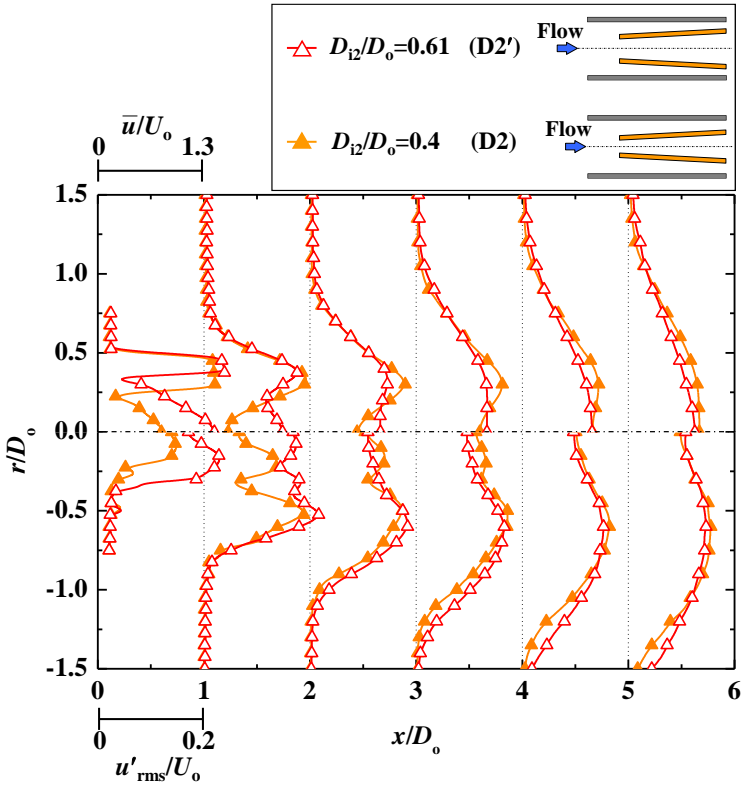

(a) Divergent tapered annulus

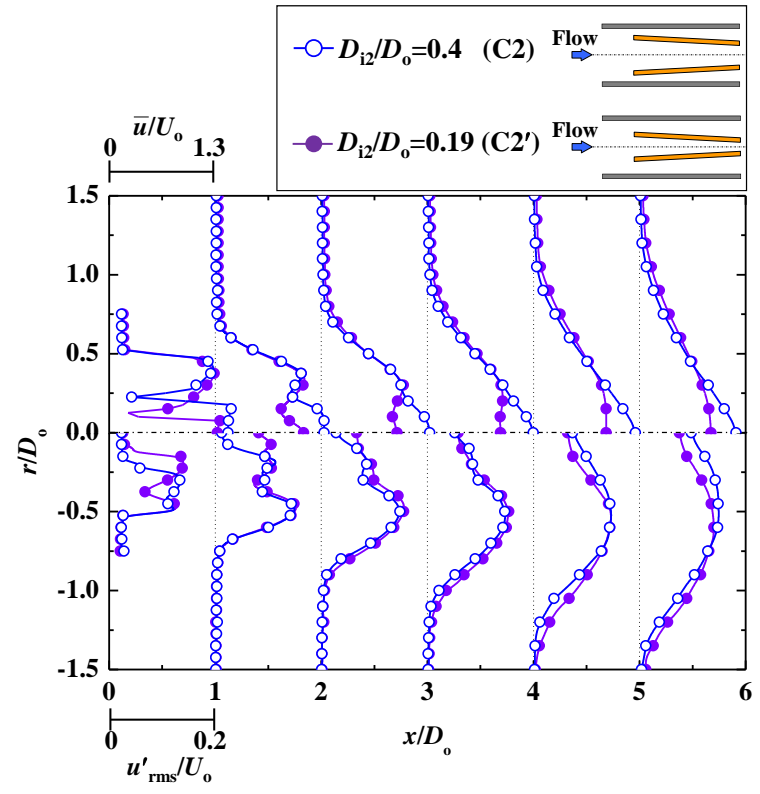

(b) Convergent tapered annulus

Fig.17 Mean axial velocity and velocity fluctuation profiles of a round jet with convergent and divergent tapered annulus (Effect of diameter). Velocity profiles of round jet with divergent annulus of $D_{\mathrm{i} 2} / D_{0}=0.4$ showed decreasing inner jet flow compared with that of $D_{\mathrm{i} 2} / D_{0}=0.61$. Velocity profiles of round jet with convergent annulus of $D_{\mathrm{i} 2} / D_{0}=0.19$ showed decreasing inner jet flow compared with that of $D_{\mathrm{i} 2} / D_{\mathrm{o}}=0.4$.

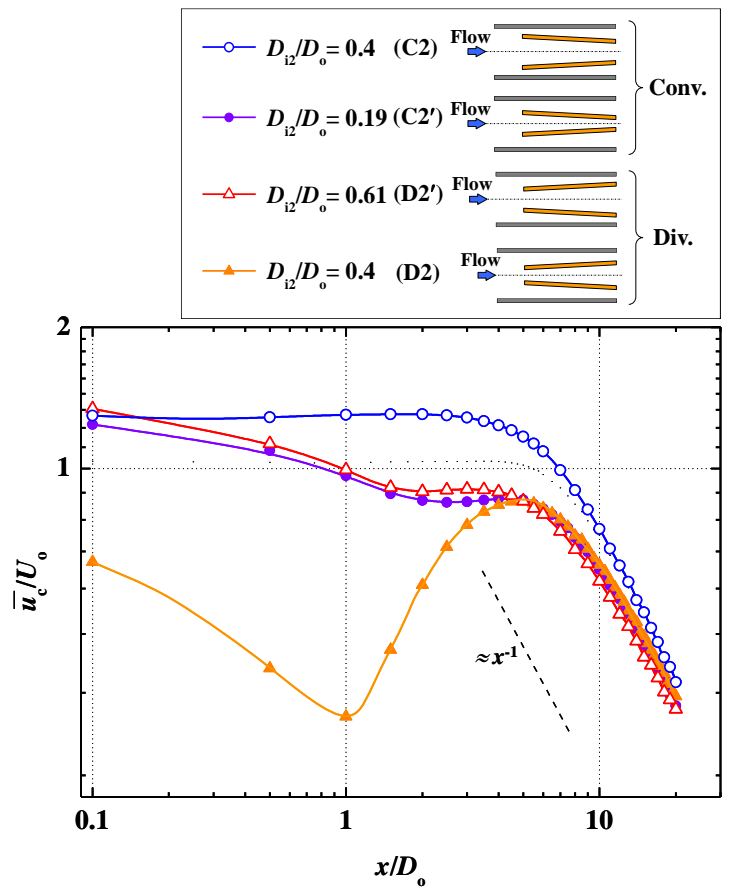

Fig.18 Mean axial velocity profiles along the centerline of a round jet with convergent and divergent tapered annulus (Effect of diameter). Velocity profiles along the centerline of round jet with divergent annulus of $D_{\mathrm{i} 2} / D_{0}=0.4$ decreased at nozzle exit of $x / D_{0}<1.0$ and increased at $x / D_{0}>1.0$.

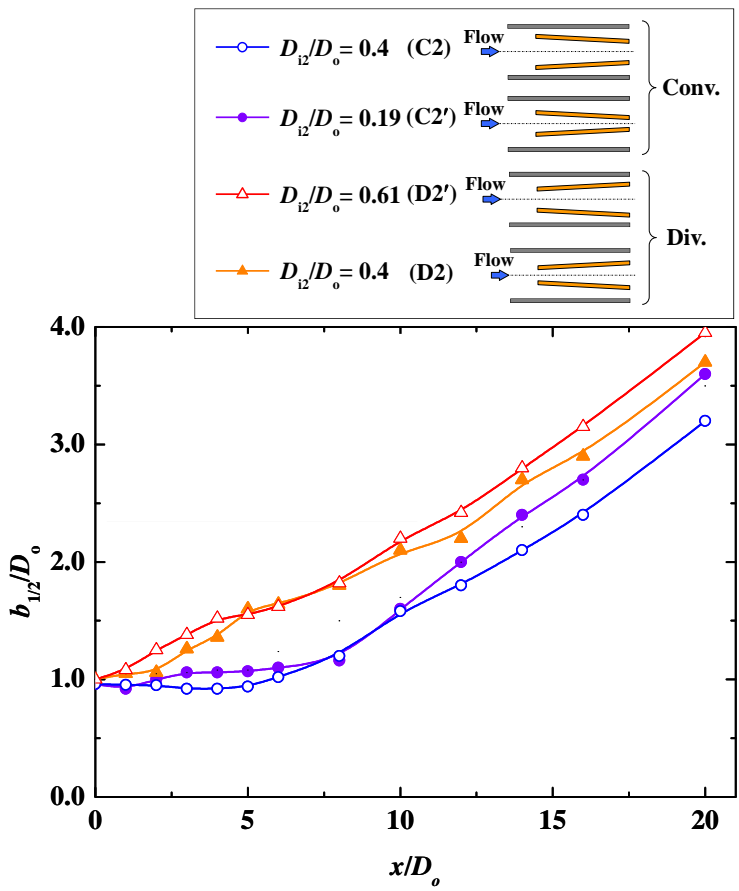

Fig.19 Half-width of a round jet with convergent and divergent tapered annulus (Effect of diameter). Half-width of a round jet with convergent annulus $\left(D_{\mathrm{i} 2} / D_{0}=0.19\right)$ and divergent annulus $\left(D_{\mathrm{i} 2} / D_{0}=0.19\right)$ increase and decrease at nozzle exit and downstream of $x / D_{0}=7.5$. 
Table 3 Velocity ratios with divergent tapered annulus

\begin{tabular}{|c|c|c|c|c|c|c|}
\hline Index & D1 & D2 & D3 & D1' & D2' & D3' \\
\hline$\alpha$ & \multicolumn{6}{|c|}{$6^{\circ}$} \\
\hline$L / D_{0}$ & 1.0 & 2.0 & 3.0 & 1.0 & 2.0 & 3.0 \\
\hline$D_{\mathrm{i} 2} / D_{\mathrm{o}}$ & \multicolumn{3}{|c|}{0.4} & 0.51 & 0.61 & 0.72 \\
\hline$A_{\mathrm{i} 1} / A_{\mathrm{i} 2}$ & 0.54 & 0.23 & 0.05 & 0.63 & 0.43 & 0.31 \\
\hline$\overline{\bar{u}_{\text {imax }}} / \bar{u}_{\text {omax }}$ & 1.03 & 0.53 & 0.10 & 0.99 & 0.90 & 0.58 \\
\hline
\end{tabular}

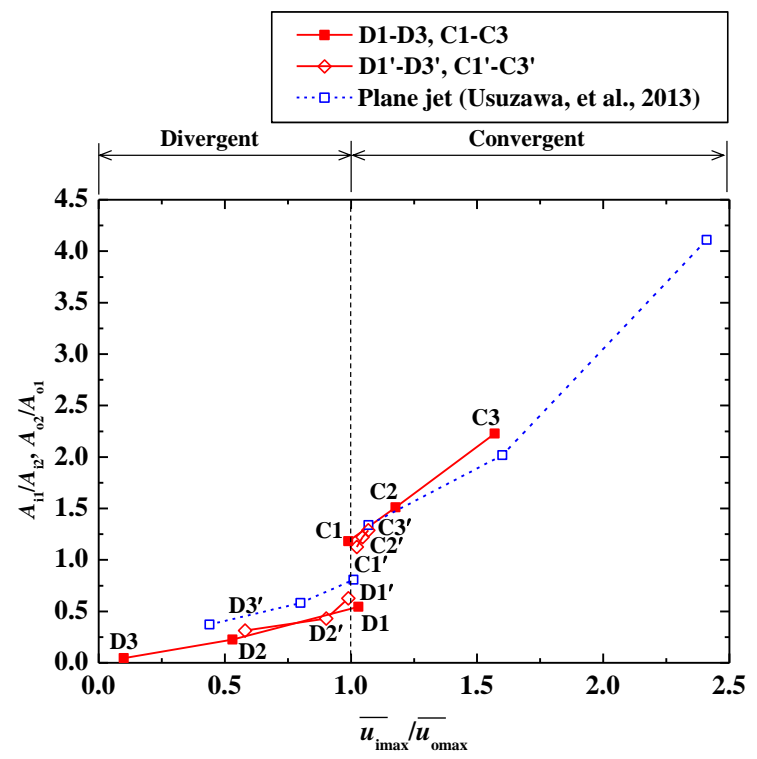

Fig.20 Variations of the area rate with $\bar{u}_{\text {imax }} / \bar{u}_{\text {omax }}$. A round jet with convergent annulus has an area rate of larger than 1.0. A round jet with divergent annulus has an area rate of smaller than 1.0. Variations of the area rate with velocity ratio of round jet with annulus are similar to that of plane jet with deflector.
Table 4 Velocity ratios of convergent tapered annulus

\begin{tabular}{|c|c|c|c|c|c|c|}
\hline Index & C1 & C2 & C3 & C1 $^{\prime}$ & C2 $^{\prime}$ & C3' $^{\prime}$ \\
\hline \hline$\alpha$ & \multicolumn{7}{|c|}{-6 $^{\circ}$} \\
\hline$L / D_{0}$ & 1.0 & 2.0 & 3.0 & 1.0 & 2.0 & 3.0 \\
\hline$D_{\text {i } 2} / D_{0}$ & \multicolumn{7}{|c|}{0.4} & & 0.30 & 0.19 & 0.085 \\
\hline$A_{\text {o2 }} / A_{\text {o1 }}$ & 1.18 & 1.51 & 2.23 & 1.13 & 1.22 & 1.29 \\
\hline$\overline{u_{\text {imax }}} / \overline{u_{\text {omax }}}$ & 0.99 & 1.18 & 1.57 & 1.02 & 1.05 & 1.07 \\
\hline
\end{tabular}

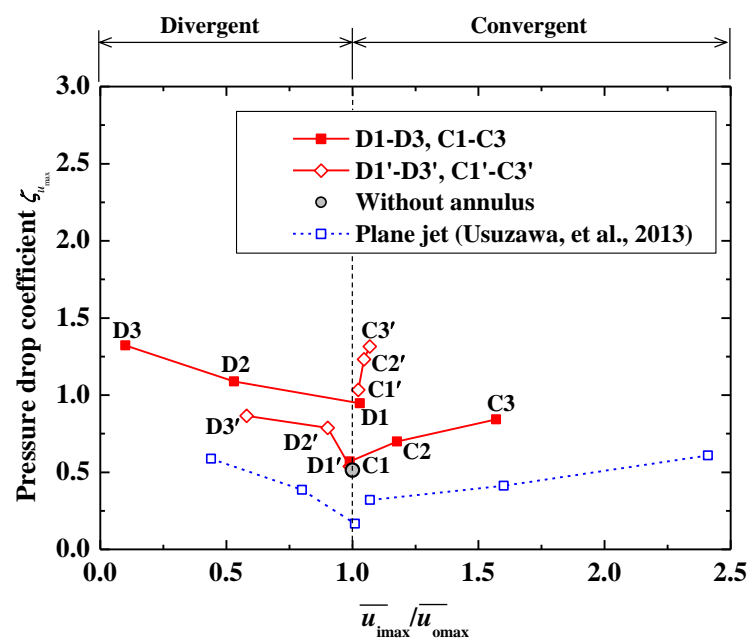

Fig.21 Variations of the pressure drop coefficient with $\bar{u}_{\text {imax }} / \bar{u}_{\text {omax }}$. Pressure drop coefficient of a round jet with convergent and divergent annulus increased with an increase of length and decrease of diameter of annulus.

ここで $x_{0}$ は仮想原点の位置を示す．なお，式(1)は噴流の下流領域 $x / D_{0}=10 \sim 20$ で適用した．また，比較のため， Sadeghi ら(Sadeghi and Pollard, 2012)によるリングなし(No ring)の円形噴流の拡散率とポテンシャルコア内に正方 形断面のリングを設置した場合(With ring)の拡散率を合わせて示す.

本実験のテーパ環なしの場合の拡散率は Sadeghi らの結果とほぼ一致する。縮小テーパ環の場合には C1 C3 の プロットを見るとテーパ環長さが $L / D_{0}=3.0$ に増加することで, 速度比が 1.0 以上になると拡散率は約 0.08 で一定 となる. C1'〜C3'の場合， C1 C3 と比較すると同じ縮小テーパ環長さでテーパ環直径を小さくしたとき $\left(\mathrm{C1}^{\prime} \sim \mathrm{C} 3^{\prime}\right)$ には，速度比が 1.0 付近で $K_{\mathrm{y}}$ が急激に増加し， $K_{\mathrm{y}}=0.115\left(\mathrm{C1}^{\prime}, \mathrm{C}^{\prime}\right)$ となる。ここで, C3'のみ $K_{\mathrm{y}}$ が小さくなるのは 内側噴流の出口直径が $3.4 \mathrm{~mm}$ と小さいためであると考えられる，一方，拡大テーパ環では，D1 D3 のプロット を見るとテーパ環長さが増加し，速度比が 1.0 以下に変化すると $K_{\mathrm{y}}$ は約 0.085 で一定となる． D1' D3'と D1 D3 を比較すると同じ拡大テーパ環長さでテーパ環直径を小さくしたとき(D1 D3)にも同様で $K_{\mathrm{y}}$ は約 0.09 で一定とな る.したがって，拡大テーパ環の長さと直径を変化させた場合には，速度比 $\bar{u}_{\text {imax }} / \bar{u}_{\text {omax }}$ によって半值幅の傾きは変 化しないことがわかる。一方，平面噴流を見ると，拡大偏向板を有する場合は円形噴流と同様の傾向を示し，偏 向板長さが増加しても $K_{\mathrm{y}}=0.10$ で一定となる. また, 平面噴流の縮小偏向板の場合は円形噴流よりも $K_{\mathrm{y}}$ の増加率 は若干増加するがその増加量は小さい. したがって, 円形噴流と平面噴流の $K_{\mathrm{y}}$ 值はともにテーパ環, 偏向板によ って変化しないといえる.

図 23 にテーパ環なし，拡大テーパ環，縮小テーパ環における仮想原点位置 $x_{0} / D_{0}$ と速度比 $\bar{u}_{\text {imax }} / \bar{u}_{\text {omax }}$ の関係を示 す．比較のため Sadeghi ら(Sadeghi and Pollard, 2012)によるリングなしの場合(No ring)の円形噴流とポテンシャル コア内にリングを設置した場合(With ring)の円形噴流の仮想原点位置を合わせて示す.テーパ環なしの場合の仮想 原点位置は-0.46 となった. C1 C3 の縮小テーパ環では, テーパ環長さの増加に伴って速度比が 1.0 以上に増加す 


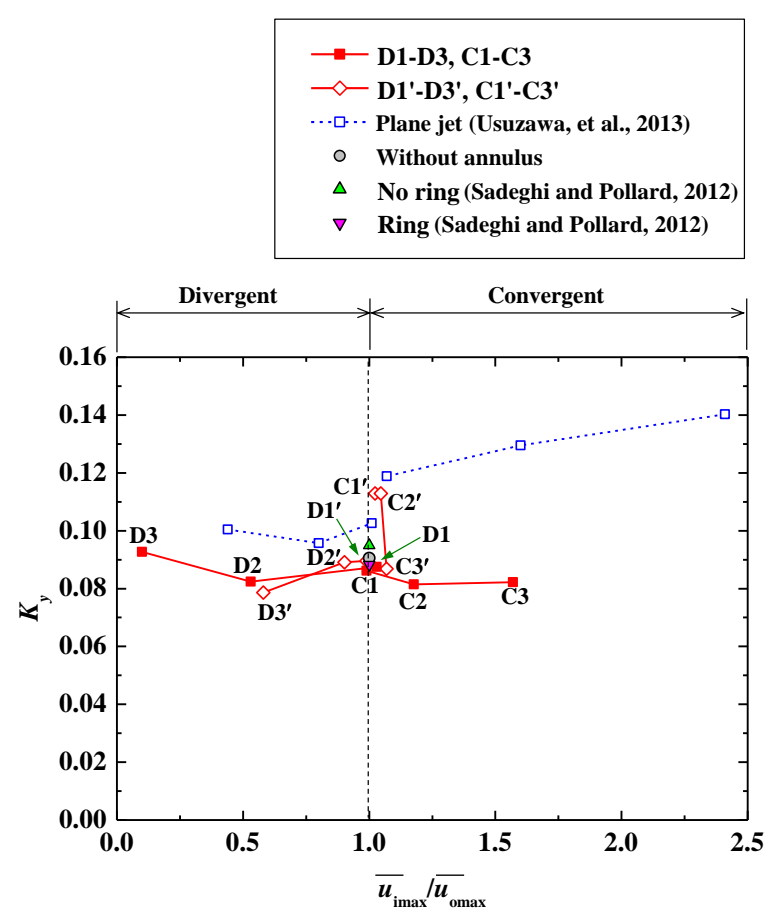

Fig.22 Variations of $K_{y}$ with $\bar{u}_{\text {imax }} / \bar{u}_{\text {omax }} K_{\text {y }}$ of a round jet with convergent and divergent annulus are almost constant due to variations of a length and diameter of annulus.

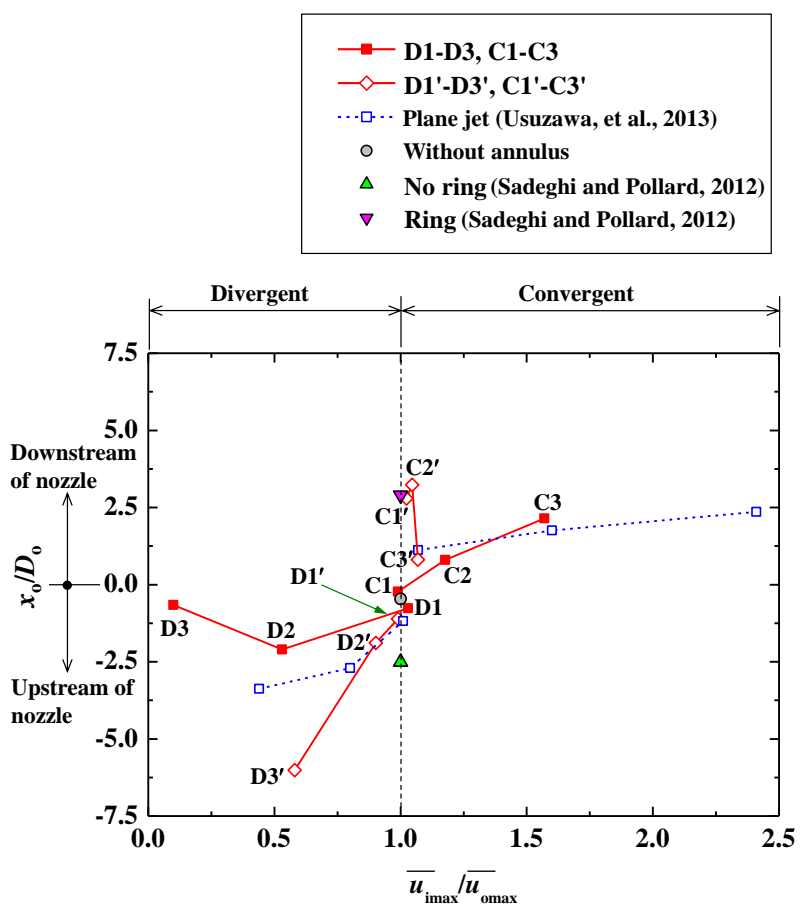

Fig.23 Variations of the virtual origin with $\bar{u}_{\text {imax }} / \bar{u}_{\text {omax }} x_{0} / D_{0}$ of a round jet with convergent annulus increased with an increase of velocity ratio. $x_{0} / D_{0}$ of a round jet with divergent annulus decreased with a decrease of velocity ratio.

ると仮想原点位置は下流側 $\left(x / D_{0}>0\right)$ 一移動していることがわかる.したがって, 図 22 で示したように半值幅の勾 配 $K_{\mathrm{y}}$ に変化がないことから, テーパ環長さが長くなるほど噴流の広がりが減少する現象は縮小テーパ環を設置す ることで仮想原点が下流へ移動していることに起因すると考えられる．ただし，C1' C3'の場合，C1 C3 と比較 すると縮小テーパ環直径が小さい場合には速度比 1.0 付近で仮想原点位置が増加する．また，縮小テーパ環直径 が小さい場合 $\left(\mathrm{C} 1^{\prime} \sim \mathrm{C} 3^{\prime}\right)$ には, 半值幅の勾配 $K_{\mathrm{y}}$ の増加と仮想原点位置の上流側 $\left(x / D_{0}<0\right)$ への移動の効果によって, 図 19 の半值幅分布に示したように結果的にテーパ環直径を変化させない場合よりも噴流の広がりは小さくなら ない. 拡大テーパ環では, テーパ環の長さの増加に伴って速度比 $\bar{u}_{\text {imax }} / \bar{u}_{\text {omax }}$ が 1.0 以下に減少すると仮想原点位置 は上流側 $\left(x / D_{0}<0\right)$ に移動する．拡大テーパ環直径が大きい場合 $\left(D 1^{\prime} \sim D 3^{\prime}\right)$ には，速度比が大きく減少すると仮想原 点位置も下流へ移動する. したがって, 円形噴流においてもテーパ環による速度比に対する面積比, 圧力損失, 拡散率，仮想原点位置の変化が平面噴流の場合と同様に生じることが明らかとなった.

\section{4. 結}

拡大テーパ環および縮小テーパ環を有する円形噴流の流れ特性に及ぼすテーパ環長さ，テーパ環直径の影響を 調べ，以下の結論を得た.

(1) 拡大テーパ環または縮小テーパ環を円形噴流のノズル内部に設置し, テーパ環の長さや直径を変化させる ことで，速度比 $\bar{u}_{\text {max }} \bar{u}_{\text {omax }}=0.10 \sim 1.57$ の同軸噴流を形成させることが可能である.

（2）拡大テーパ環を設置した場合の円形噴流は，テーパ環内側表面で流れが剥離し，ノズル出口で内側噴流が 減速, 外側噴流が増速される. 外側噴流の増速により, 外側噴流と周囲流体の間のせん断層の乱れ強さが増加し, 周囲流体との混合が促進されるためにテーパ環を設置しない円形噴流よりも噴流の広がりが増大寸る. そして, 偏向板を有する平面噴流(臼沢他, 2013) と同様に，テーパ環長さや直径が変化しても拡散率 $K_{\mathrm{y}}$ は変化せず，仮想 原点位置 $x_{0} / D_{0}$ がノズル出口上流側に移動するため見かけ上の噴流の広がりが増加する. 
（3）縮小テーパ環を設置した場合の円形噴流は，テーパ環外側表面で流れが剥離し，ノズル出口で内側噴流が 増速，外側噴流が減速する．縮小テーパ環では外側噴流と周囲流体との間のせん断層の乱れ強さが増加しないた め, 縮小テーパ環を設置しない円形噴流よりも噴流の広がりが減少する. そして, 偏向板を有する平面噴流(臼沢 他, 2013) と同様に拡散率 $K_{\mathrm{y}}$ は変化せず，仮想原点位置 $x_{0} / D_{0}$ がノズル出口下流側に移動するため見かけ上の噴流 の広がりが減少する.

（4）拡大・縮小テーパ環を有する円形噴流の速度比と面積比 $A_{\mathrm{i} 1} / A_{\mathrm{i} 2}, A_{02} / A_{01}$, 圧力損失係数 $\zeta_{\text {umax }}$, 拡散率 $K_{\mathrm{y}}$, 仮想原点位置 $x_{0} / D_{0}$ は平面噴流の実験結果と同様の傾向を示寸. 速度比は縮小テーパ環の外側面積比 $A_{02} / A_{01}$, 拡 大テーパ環の内側面積比 $A_{\mathrm{i} 1} / A_{\mathrm{i} 2}$ によって整理できること, 圧力損失係数はノズル出口の最大速度で無次元化した 圧力損失係数で整理できることを示した.

\section{謝 辞}

本研究の一部は日本学術振興会科学研究費基盤研究(C)(No.22560160)によって行われた. また, 実験遂行にあた り本学技術職員の倉谷知宏氏および，当時学類 4 年の好田郁弥君の協力を得た。ここに記して謝意を表す.

\section{文献}

Burattini, P., Antonia, R.A., Rajagopalan, S. and Stephens, M., Effect of initial conditions on the near-field development of a round jet, Experiments in fluids, Vol.37 (2004), pp.56-64.

Burattini, P. and Djenidi, L., Velocity and passive scalar characteristics in a round jet with grids at the nozzle exit, Flow, Turbulence and Combustion, Vol.72, No.2 (2004), pp.199-218.

Buresti, G., Petagna, P. and Talamelli, A., Experimental investigation on the turbulent near-field of coaxial jets, Experimental Thermal and Fluid Science, Vol.17 (1998), pp.18-26.

Callender, B., Gutmark, E.J. and Martens, S., Flow field characterization of coaxial conical and serrated (chevron) nozzles, Experiments in fluids, Vol.48 (2010), pp.637-649.

Champagne, F.H. and Wygnanski, I.J., An experimental investigation of coaxial turbulent jets, International Journal of Heat and Mass Transfer, Vol.14 (1971), pp.1445-1464.

木綿隆弘, 岡島厚, 上野久儀, 西隆司, 中川正人, 同軸二重円管噴流の再循環領域とせん断層洞構造, 日本機械学 会論文集 B 編, Vol.60, No.575 (1994), pp.112-119.

Ko, N.W.M. and Kwan, A.S.H., The initial region of subsonic coaxial jets, Journal of fluid Mechanics, Vol.73, No.2 (1976), pp.305-332.

Ko, N.W.M. and Au, H., Initial region of subsonic coaxial jets of high mean-velocity ratio, Transactions ASME, Journal of Fluids Engineering, Vol.103 (1981), pp.335-338.

Mergheni, M.A., Boushaki, T., Sautet, J.C., Godard, G., Ticha, H.B. and Nasrallah, S.B., Effects of different mean velocity ratios on dynamics characteristics of a coaxial jet, Thermal science, Vol.12, No.2 (2008), pp.49-58.

Parker, R., Rajagopalan, S. and Antonia, R.A., Control of an axisymmetric jet using a passive ring, Experimental Thermal and Fluid Science, Vol.27, No.5 (2003), pp.545-552.

Sadeghi, H. and Pollard, A., Effects of passive control rings positioned in the shear layer and potential core of a turbulent round jet, Physics of fluids, Vol.24, No.115103 (2012), pp.1-21.

Schlichting, H., Boundary Layer Theory (1986), 7th ed., McGrow-Hill.

臼沢太一, 木綿隆弘, 樋本航，ノズル内部に偏向板を設置した平面噴流の流れ特性，日本機械学会論文集 B 編, Vol.79, No.808 (2013), pp.192-206.

Warda, H.A., Kassab, S.Z., Elshorbagy, K.A. and Elsaadawy, E.A., An experimental investigation of the near-field region of a free turbulent coaxial jet using LDA, Flow Measurement and Instrumentation, Vol.10 (1999), pp.15-26.

\section{References}

Burattini, P., Antonia, R.A., Rajagopalan, S. and Stephens, M., Effect of initial conditions on the near-field development of a round jet, Experiments in fluids, Vol.37 (2004), pp.56-64.

Burattini, P. and Djenidi, L., Velocity and passive scalar characteristics in a round jet with grids at the nozzle exit, Flow, 
Turbulence and Combustion, Vol.72, No.2 (2004), pp.199-218.

Buresti, G., Petagna, P. and Talamelli, A., Experimental investigation on the turbulent near-field of coaxial jets, Experimental Thermal and Fluid Science, Vol.17 (1998), pp.18-26.

Callender, B., Gutmark, E.J. and Martens, S., Flow field characterization of coaxial conical and serrated (chevron) nozzles, Experiments in fluids, Vol.48 (2010), pp.637-649.

Champagne, F.H. and Wygnanski, I.J., An experimental investigation of coaxial turbulent jets, International Journal of Heat and Mass Transfer, Vol.14 (1971), pp.1445-1464.

Kiwata, T., Okajima, A., Ueno, H., Nishi, T. and Nakagawa, M., Recirculating cells and vortex structure in shear layers of double coaxial pipe jets, Transactions of the Japan Society of Mechanical Engineers, Series B, Vol.60, No.575 (1994), pp.112-119 (in Japanese).

Ko, N.W.M. and Kwan, A.S.H., The initial region of subsonic coaxial jets, Journal of fluid Mechanics, Vol.73, No.2 (1976), pp.305-332.

Ko, N.W.M. and Au, H., Initial region of subsonic coaxial jets of high mean-velocity ratio, Transactions ASME, Journal of Fluids Engineering, Vol.103 (1981), pp.335-338.

Mergheni, M.A., Boushaki, T., Sautet, J.C., Godard, G., Ticha, H.B. and Nasrallah, S.B., Effects of different mean velocity ratios on dynamics characteristics of a coaxial jet, Thermal science, Vol.12, No.2 (2008), pp.49-58.

Parker, R., Rajagopalan, S. and Antonia, R.A., Control of an axisymmetric jet using a passive ring, Experimental Thermal and Fluid Science, Vol.27, No.5 (2003), pp.545-552.

Sadeghi, H. and Pollard, A., Effects of passive control rings positioned in the shear layer and potential core of a turbulent round jet, Physics of fluids, Vol.24, No.115103 (2012), pp.1-21.

Schlichting, H., Boundary Layer Theory (1986), 7th ed., McGrow-Hill.

Usuzawa, T., Kiwata, T. and Hinomoto, W., Flow characteristics of a plane jets with deflectors inside the nozzle, Transactions of the Japan Society of Mechanical Engineers, Series B, Vol.79 , No.808 (2013), pp.192-206 (in Japanese).

Warda, H.A., Kassab, S.Z., Elshorbagy, K.A. and Elsaadawy, E.A., An experimental investigation of the near-field region of a free turbulent coaxial jet using LDA, Flow Measurement and Instrumentation, Vol.10 (1999), pp.15-26. 